\title{
Five well-supported fossil calibrations within the "Waterbird" assemblage (Tetrapoda, Aves)
}

\author{
Nathan D. Smith and Daniel T. Ksepka
}

\begin{abstract}
The "waterbird" assemblage is a group of aquatic and semi-aquatic birds that are characterized by extremely diverse morphologies, ecologies, and life histories. The group also includes fossil representatives that constitute some of the oldest records of Neoaves and are critical to calibrating the temporal diversification of modern birds. Herein, we provide a set of five well-supported fossil calibrations from the waterbird clade that will serve to provide robust temporal calibrations for the origins of: stem Phaethontes (tropicbirds); stem Threskiornithidae (ibises and spoonbills); stem Pelecanidae (pelicans); stem Fregatidae (frigatebirds); and stem Phalacrocoracidae (cormorants). We apply stringent criteria to justify both the phylogenetic placement and geochronologic context of these specimens, and discuss potentially older records to help focus future research and collection. The fossils described here affirm previous studies in recognizing that most major cladogenetic splits within the waterbird assemblage occurred by the Eocene, supporting interpretations of both rapid lineage diversification of waterbirds in the early Paleogene, and also the rapid establishment of body plans and possibly ecologically relevant morphologies during this time period.
\end{abstract}

Nathan D. Smith. Department of Biology, Howard University, 415 College Street NW, Washington, DC 20059, USA and Department of Paleobiology, National Museum of Natural History, Smithsonian Institution, Washington, DC 20013 USA. nathan.smith@howard.edu

Daniel T. Ksepka. Bruce Museum, 1 Museum Drive, Greenwich, Connecticut 06830, USA.

dksepka@brucemuseum.org

Keywords: Aves; Pelecaniformes; fossil calibrations; phylogeny; molecular clock

\section{INTRODUCTION}

The 'waterbird' assemblage ("Natatores" sensu Livezey and Zusi, 2007; "Aequornithes" sensu Mayr, 2011a) is a diverse avian group that includes loons, penguins, herons, pelicans, and their allies. The group has a disparate set of morphologies, ecologies, and life history strategies

PE Article Number: 18.1.7FC

Copyright: Society for Vertebrate Paleontology April 2015

Submission: 29 April 2014. Acceptance: 1 April 2015

Smith, Nathan D. and Ksepka, Daniel T. 2015. Five well-supported fossil calibrations within the "Waterbird" assemblage (Tetrapoda, Aves). Palaeontologia Electronica 18.1.7FC; 1-21;

palaeo-electronica.org/content/fc-7

Calibrations published in the Fossil Calibration Series are accessioned into the Fossil Calibration Database (www.fossilcalibrations.org). The Database is a dynamic tool for finding up-to-date calibrations, and calibration data will be updated and annotated as interpretations change. In contrast, the Fossil Calibration papers are a permanent published record of the information on which the calibrations were originally based. Please refer to the Database for the latest data. 
TABLE 1. Fossil calibrations within the waterbird assemblage.

\begin{tabular}{|c|c|c|c|c|c|}
\hline Calibration & Node & Taxon & Specimen & Geological Context & $\begin{array}{l}\text { Minimum } \\
\text { Age }\end{array}$ \\
\hline 1 & $\begin{array}{l}\text { Phaethontidae + extant } \\
\text { sister taxon }\end{array}$ & $\begin{array}{l}\text { Lithoptila } \\
\text { abdounensis }\end{array}$ & OCP.DEK/GE 1087 & $\begin{array}{l}\text { Bed Ila, Ouled Abdoun } \\
\text { Basin, Morocco }\end{array}$ & $56.0 \mathrm{Ma}$ \\
\hline 2 & $\begin{array}{l}\text { Threskiornithidae + extant } \\
\text { sister taxon }\end{array}$ & Rhynchaeites sp. & MGUH 20288 & $\begin{array}{l}\text { Fur Formation, NE } \\
\text { Denmark }\end{array}$ & $53.9 \mathrm{Ma}$ \\
\hline 3 & $\begin{array}{l}\text { Pelecanidae + extant sister } \\
\text { taxon }\end{array}$ & Pelecanus sp. & NT-LBR-039 & $\begin{array}{l}\text { Pichovet limestone } \\
\text { deposits, SE France }\end{array}$ & $28.1 \mathrm{Ma}$ \\
\hline 4 & Fregatidae + Suloidea & $\begin{array}{l}\text { Limnofregata } \\
\text { azygosternon }\end{array}$ & USNM 22753 & $\begin{array}{l}\text { Green River Formation, } \\
\text { Wyoming, USA }\end{array}$ & $51.81 \mathrm{Ma}$ \\
\hline 5 & $\begin{array}{l}\text { Phalacrocoracidae + } \\
\text { Anhingidae }\end{array}$ & $\begin{array}{l}\text { ?Borvocarbo } \\
\text { stoeffelensis }\end{array}$ & PW 2005/5022-LS & $\begin{array}{l}\text { Enspel Lagerstätte, W } \\
\text { Germany }\end{array}$ & $24.52 \mathrm{Ma}$ \\
\hline
\end{tabular}

(Smith, 2010; Simons et al., 2011; Smith, 2012; Felice and O'Connor, 2014). Relationships within the waterbird assemblage have also been fairly controversial, with morphological (Livezey and Zusi, 2007; Smith, 2010; Mayr, 2011b) and molecular (Fain and Houde, 2004; Ericson et al., 2006; van Tuinen et al., 2006; Brown et al., 2008; Hackett et al., 2008; Gibb et al., 2013; McCormack et al., 2013) analyses often differing considerably in ingroup topologies, particularly in regard to the monophyly and relationships of the traditional avian orders Ciconiiformes and Pelecaniformes. In addition, though most analyses are consistent in recovering a "core" group of waterbirds, a growing number of molecular datasets are recovering tropicbirds (Phaethontidae); grebes (Podicipedidae), and flamingos (Phoenicopteridae) as distantly related to other waterbirds, with strong support for a sister-taxon relationship between grebes and flamingos (van Tuinen et al., 2001; Fain and Houde, 2004; Ericson et al., 2006; Hackett et al., 2008). A lack of consensus on higher-level relationships within the waterbird assemblage has hindered progress toward understanding aspects of their temporal diversification and broader evolutionary patterns (Smith, 2010). This phylogenetic uncertainty also warrants caution in uncritically accepting taxonomic identifications of fossil members of waterbird clades that may help inform on these temporal patterns (Ksepka et al., 2011).

A variety of waterbird fossils have previously been utilized in divergence time estimation studies of higher-level avian phylogeny (e.g., Ericson et al., 2006; van Tuinen et al., 2006; Brown et al., 2008). Additionally, potential fossil calibrations for numerous groups within the waterbird assemblage have been discussed in the literature (Dyke and van Tuinen, 2004; Lindow and Dyke, 2006; Mayr, 2009a, 2014; Smith, 2010; Smith et al., 2013). However, in very few cases have these waterbird fossils actually been justified as calibrations following a 'best practices' approach that emphasizes explicit phylogenetic and geochronological criteria be marshaled to support fossil calibrations (Parham et al., 2012). Herein we present five well-justified fossil calibrations (Table 1) for members of the traditional avian orders Pelecaniformes and Ciconiiformes within the waterbird clade. These calibrations follow the 'best practices' guidelines recently described by Parham et al. (2012), which emphasize: 1) establishing each calibration on a single specimen (though in some cases we discuss additional specimens that support a calibration as well); 2) establishing the phylogenetic relationships of this calibration through either a phylogenetic analysis that supports its sister-taxon relationships, or an explicit apomorphy-based diagnosis (e.g., Bell et al., 2004; Bever, 2005; Nesbitt and Stocker, 2008) that does the same; 3 ) resolving any conflict between morphological and molecular phylogenetic datasets regarding both the relationships of the fossil calibration, and the node being calibrated; 4) providing a detailed description of the geographic locality and stratigraphic context of the specimen serving as a calibration; and 5) providing a chain of evidence between this stratigraphic context and a specific temporal age, based on either a radioisotopic date (preferable) or reference to a numeric geological timescale.

We place an emphasis on identifying hard minimum ages for the phylogenetic nodes being calibrated, which includes the estimated age of a fossil specimen, as well as the error associated with that age (van Tuinen et al., 2004; Benton and Donoghue, 2007; Donoghue and Benton, 2007; Ho and Phillips, 2009; Parham et al., 2012). Although maximum age constraints may be particularly useful for informing clade age distribution priors in 
analyses of temporal diversification (e.g., Thorne et al., 1998; Yang and Rannala, 2006; Yang, 2007; Drummond et al., 2006; Drummond and Rambaut, 2007), establishing maximum constraints is not as straightforward as justifying hard minima (Müller and Reisz, 2005; Benton and Donoghue, 2007; Donoghue and Benton, 2007; Ho and Phillips, 2009; Parham et al., 2012), and the implications of maximum age constraint/parameter misspecification has only recently been explored (Ho and Phillips, 2009; Inoue et al., 2010; Clarke et al., 2011; Lee and Skinner, 2011; Parham et al., 2012; Warnock et al., 2012). Coupled with the heterogeneous nature of the avian fossil record and phylogenetic uncertainty of higher-level relationships, we feel it is imprudent to assign maximum age constraints to the higher-level waterbird nodes discussed here. We utilized the Geological Time Scale 2012 (Gradstein et al., 2012; Walker et al., 2013), and the International Chronostratigraphic Chart (Cohen et al., 2013) when translating global stratigraphic boundaries into numeric ages in cases where direct radiometric dates could not be tied directly to fossil specimens (note that these two estimates of global chronostratigraphy are not independent of each other). The waterbird calibrations described here are by no means an exhaustive list, but include those that we believe are the most robust and well-supported calibrations currently, and those that offer the most potential for providing information about temporal diversification within the waterbird assemblage.

\section{MATERIALS AND METHODS}

\section{Institutional Abbreviations}

BMS, Buffalo Museum of Science, Buffalo, New York, USA; FMNH, The Field Museum of Natural History, Chicago, Illinois, USA; FSL, Université Lyon 1, Villeurbanne, France; GMNH, Gunma Museum of Natural History, Tomioka, Gunma Prefecture, Japan; MGUH, Geological Museum of the University of Copenhagen, Denmark; NHMUK (formerly BMNH), Natural History Museum, London, United Kingdom; NT, N. Tourment collection, Marseille, France; OCP.DEK/GE, Office Chérifien des Phosphates, Direction des Exploitations de Khouribga, Service Géologie, Khouribga, Morocco; PW, Landesamt für Denkmalpflege Rheinland-Pfalz, Mainz, Germany; SMF, Forschungsinstitut Senckenberg, Frankfurt am Main, Germany; USNM, National Museum of Natural History, Smithsonian Institution, Washington, D.C., USA; UWGM, Uni- versity of Wyoming Geological Museum, Laramie, Wyoming, USA.

\section{STEM PHAETHONTES}

\section{Tropicbirds}

Node Calibrated. This node represents the split between Phaethontidae and their extant sister taxon, which has not been rigorously established by phylogenetic studies at this point.

Fossil Taxon. Lithoptila abdounensis Bourdon et al. 2005.

Specimen. OCP.DEK/GE 1087 (partial skull)

Phylogenetic Justification. Phylogenetic justification is based on analyses of morphological data (Bourdon et al., 2005; Smith, 2010). The analysis of Smith (2010) recovered 10 unambiguous cranial synapomorphies of Phaethontes, with four of these exhibiting no homoplasy on the most-parsimonious trees. The synapomorphies supporting Phaethontes, presented in the format: "Character(character state)", with boldface indicating no homoplasy in the character on the most-parsimonious trees, include: 29(1) Quadrate, orientation of the squamosal and otic condyles relative to the long axis of the skull: nearly perpendicular, angle between $75-90^{\circ}$; 50(1) Squamosal, relative length of rostral border of squamosal that joins zygomatic process and caudal wall of orbit: elongate and thin, with constant thickness throughout; 54(1) Squamosal/ Prootic, pila otica elongated, strongly protruding caudoventrolaterally, so that cotyla quadratica otici faces laterally: present; 64(1) Parasphenoid, lamina parasphenoidalis ('basitemporal plate') essentially flat and rostrolaterally bordered by marked osseous walls, tubercula basilaria well-developed: yes; 68(1) Dorsal tympanic recess, greatly enlarged, much longer than large, extending rostral to and between cotylae quadratica in a figure-8 shape: present; 72(1) Foramen nervi maxillomandibularis location relative to entrance of recessus tympanicus rostralis: caudal; 83(1) Cranium, elongate, concave, triangular lamina bordered by cristae (i) nuchalis transversae, (ii) nuchalis lateralis, (iii) otica dorsalis, and (iv) post zygomatica, status: present. Mayr (2015a, p. 59) described an additional character supporting Phaethontes monophyly which is also present in OCP.DEK/GE 1087: "strongly developed and laterally prominent processus postorbitalis, which, in dorsoventral view, contributes to a marked semicircular concavity of the skull in the area of the fossa temporalis." Although laterally prominent postorbital processes are plesiomorphic for waterbirds (see Smith, 2010, 
character 47), the distinct shape of these processes in Lithoptila, Prophaethon, and Phaethon most likely represents a synapomorphy of Phaethontes.

Additionally, there are several synapomorphies present in referred specimens of Lithoptila (Bourdon et al., 2008) that also support a relationship between Lithoptila and Phaethontidae (Smith, 2010). These include: 223(2) Humerus, relative location of muscle scar for insertion of $\mathrm{M}$. pronator superficialis (= "m. pronator brevis"): only slightly posterior, and proximal to tuberculum supracondylare ventrale; 433(1) Tarsometatarsus, degree of development of area of origin for $\mathrm{m}$. abductor digiti $\mathrm{IV}$, and also passage/sulcus for joint tendon of $\mathrm{m}$. fibularis longi and $\mathrm{m}$. flexor perforans et perforatus digiti III on the lateral half of the plantar face of the tarsometatarsal shaft: well-excavated and distinct sulcus, distally extensive; 437(1) Tarsometatarsus, relative development of distal end of sulcus extensorius in area of foramen vasculare distale: sulcus extremely deep.

Minimum Age. $56.0 \mathrm{Ma}$

Soft Maximum Age. None specified.

Age Justification. OCP.DEK/GE 1087 was collected from Bed Ila, Ouled Abdoun Basin, from near Grand Daoui (Recette 4 + Sidi Daoui; see also Gheerbrant et al., 2003, figure 3), Morocco. This horizon can be constrained only to the level of the Thanetian stage. Tethyan phosphates of the Ouled Abdoun Basin (Oulad Abdoun of some authors) span the Late Cretaceous (Maastrichtian) to middle Eocene (Lutetian). These deposits have been extensively mined, and individual units are dated primarily based on biostratigraphy. No radiometric ages have yet been reported from the stratigraphic section yielding Lithoptila abdounensis. The holotype specimen was collected from an unspecified quarry but can be assigned to Bed Ila of the mining lithostratigraphical terminology (Office Chérifien des Phosphates, 1989; Gharbi, 1998), based on selachians identified in the matrix (Bourdon et al., 2005). As both the numerical age of Bed lla deposits and the precise horizon from which the Lithoptila abdounensis holotype was collected remain uncertain, we conservatively suggest the entire span of the Thanetian (56.0-59.2 Ma; Gradstein et al., 2012; Walker et al., 2013) be included in the possible range of ages for this taxon. Following best practices for justifying minimum age constraints (Parham et al., 2012), we apply the youngest possible age for the Thanetian, inclusive of error: 56.0 Ma.
Phylogenetic position of Phaethontes and Lithoptila abdounensis. Phaethontes is used as the name for the larger clade uniting Prophaethontidae (Lithoptila abdounensis + Prophaethon shrubsolei) and Phaethontidae (Olson, 1985). Higher-level relationships of Phaethontes remain poorly understood. Fain and Houde (2004) were among the first to provide robust molecular support that tropicbirds were not allied with other Pelecaniformes, recovering them as sister taxon to a swift + hummingbird clade in a much larger, diverse group termed "Metaves". Ericson et al. (2006) were unable to completely resolve the position of Phaethontidae but recovered a large polytomy including Phaethontidae, Pteroclididae, Mesitornithidae, and Columbiformes and several other taxa of "Metaves". A large-scale analysis of mitochondrial genomes recovered Phaethontidae as the sister taxon to Sphenisciformes (penguins) with a group including most Pelecaniformes (though Pelecanidae was not included in this analysis), as the successive sister taxon to this clade (Brown et al., 2008). In a phylogenomic analysis, Hackett et al. (2008) recovered Phaethontidae as sister to a clade uniting Pteroclididae, Mesitornithidae, and Columbiformes, but the branch subtending this clade is one of the least well-supported in the tree. In contrast, morphological analyses have tended to place Phaethontes in a far removed position, united either with Procellariiformes (Bourdon et al., 2005; Smith, 2010) or Pelecaniformes (Livezey and Zusi, 2006, 2007).

Placement of the fossil taxon on the tropicbird stem lineage is less controversial. Bourdon et al. (2005) conducted a phylogenetic analysis that recovered a clade uniting Lithoptila abdounensis and the Eocene Prophaethon shrubsolei as the sister taxon of the extant Phaethontidae. In a more recent phylogenetic analysis, Smith (2010) instead found Lithoptila and Prophaethon to form successive sister taxa to Phaethontidae. This slight difference does not affect the utility of Lithoptila as a calibration point for stem Phaethontes.

Fossil record of Phaethontes. Widely geographically distributed fossils that represent stem members of the tropicbird lineage are known from the Paleogene, Eocene, and Miocene. These occurrences result in relatively small temporal gaps in the early record (late Paleocene-middle Eocene) of tropicbirds, though each temporal data point comprises very few specimens. The record of morphological evolution for tropicbirds is likewise very sparse due to the incomplete nature of most fossils reported thus far. It has been suggested that the 
poor Miocene record of trobicbirds could be due to a shift to strictly pelagic habits, similar to modern Phaethon which breed on offshore islands (Olson and Walker, 1997; Mayr, 2015a). Additional Paleocene records include fragmentary remains assigned to Prophaethon sp. from the Thanetian (note that the now discarded Landenian stage name is referenced in the original description) Aquia Formation of Maryland (Olson, 1994). Although these specimens overlap in age with Lithoptila abdounensis, we prefer to use the more complete specimen to define the calibration. Early Eocene specimens from Intercalary Beds 1/2 (lowermost Ypresian) and Bed 1 (lower Ypresian) of the Phosphates Series of Ouled Abdoun Basin, which overlay the Bed Ila horizon have also been assigned to Lithoptila abdounensis (Bourdon et al., 2008). Because these specimens do not overlap the holotype, assignment to the species rests on the assumption of a single species of Prophaethontidae in the deposits. Regardless, morphologies of these fossils support assignment to Phaethontes. Two specimens, including nearly complete skulls and partial skeletons of Prophaethon shrubsolei from the early Eocene London Clay of the Isle of Sheppey represent the most substantial record of stem Phaethontidae (Andrews, 1899; Harrison and Walker, 1976a; Mayr, 2015a). Although Harrison and Walker (1976a, p. 24) considered the closely related Prophaethon to represent "an intraordinal link" between Pelecaniformes, Charadriiformes, and Procellariiformes, this taxon is now widely recognized as a member of tropicbird lineage (Olson, 1985; Bourdon et al., 2005). Middle Eocene remains from Belgium have also been reported (Mayr and Smith, 2002a).

The wide range of possible sister taxa and poor support levels recovered for most proposed relationships preclude meaningful discussion of the congruence between the fossil record of tropicbirds and their sister taxon at this time.

\section{STEM THRESKIORNITHIDAE}

\section{Ibises and Spoonbills}

Node Calibrated. This node represents the split between Threskiornithidae (ibises and spoonbills) and their extant sister taxon, which has been variable among molecular (Ericson et al., 2006; Hackett et al., 2008) and morphological (Livezey and Zusi, 2007; Smith, 2010; Mayr, 2011b) estimates of phylogeny.

Fossil Taxon. Rhynchaeites sp.
Specimen. MGUH 20288 (caudal vertebrae, partial sternum, partial pelvis, distal femur, nearly complete left and right legs from the tibiotarsi to phalanges).

Phylogenetic Justification. The referral of MGUH 20288 to Rhynchaeites sp. is based on the following combination of characters, distributed throughout the postcranial skeleton (potential autapomorphies of Rhynchaeites indicated with an asterisk): sternum with a wide trabecula mediana bounded by a single pair of caudal incisions (of similar depth to Rhynchaeites messelensis); a metatarsal I with a shorter and wider articular process for the tarsometatarsus than in extant Threskiornithidae; *a proximomedially projecting medial portion of the proximal tarsometatarsus (a distinct, but somewhat similar character is present in Gavia, Podiceps, and some procellariiforms; see Smith, 2010, character 411); the fossa for metatarsal I is located close to the medial surface of the shaft of the tarsometatarsus (a fossa in a fully medial position is present in Plotopteridae; see Smith, 2010:Character 435); *the presence of a short tendinal ossification on the plantar surface of the tarsometatarsus; and near-identical proportions of the hindlimb and pedal segments (which are also distinct from extant Threskiornithidae), with the exception that MGUH 20288 is slightly larger than some Rhynchaeites messelensis specimens (Mayr and Bertelli, 2011, table 1).

Phylogenetic placement of Rhynchaeites messelensis (Figure 1.2) as a member of total group Threskiornithidae is based on three apomorphic characters discussed by Peters (1983) and Mayr (2002a): an elongate recurved bill; a schizorhinal bill with a dorsoventrally broad basal segment of the ventral bar, and a notarium consisting of at least three fused thoracic vertebrae (Livezey and Zusi, 2006, character 892). Within waterbirds, a notarium is present in Podicipedidae, Phoenicopteridae, Threskiornithidae, and Pelecanidae (Livezey and Zusi, 2006; though in Pelecanidae, only two vertebrae anterior to the synsacrum are included, leading these authors to suggest that this taxon does not have a notarium sensu stricto). Additional potential apomorphies (optimization as apomorphies dependent upon topology of extant waterbird lineages relative to Threskiornithidae) uniting Rhynchaeites messelensis and Threskiornithidae include: 1) a dorsoventrally deep sternal keel (Livezey and Zusi, 2006, character 1199; see also Smith, 2010, character 133); 2) a postacetabular blade of the ilium that is as long as or extends further caudally than the caudal end of the ischium 


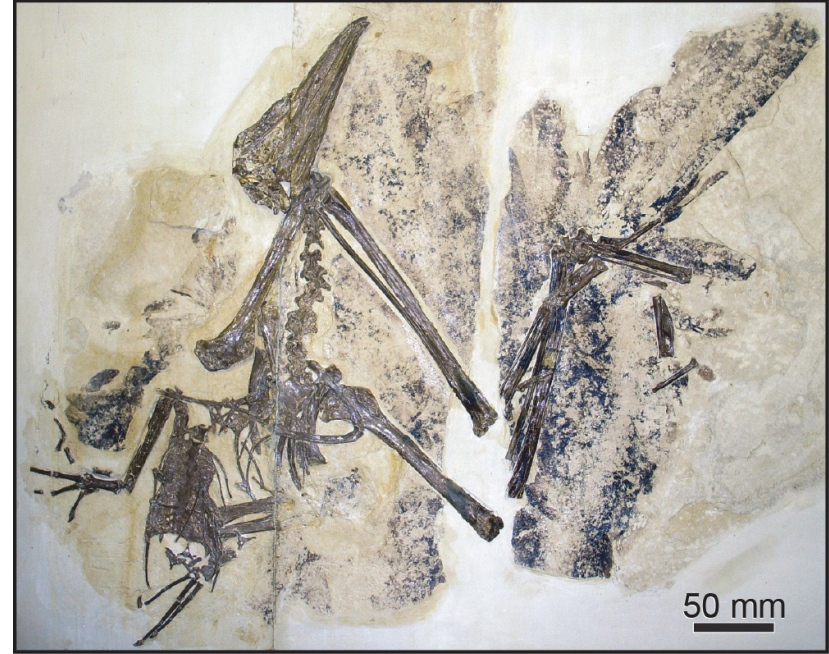

1

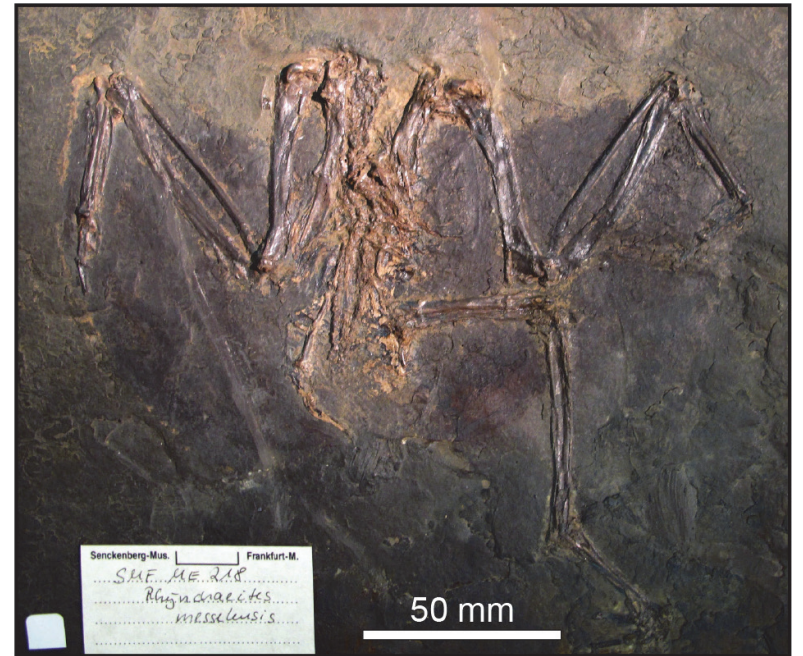

2

FIGURE 1. Specimens representative of two taxa that provide fossil calibrations within the waterbird assemblage. 1, Limnofregata azygosternon (USNM 22753) from the early Eocene Green River Formation represents the sister taxon (with its congener Limnofregata hasegawai) to Fregata, and calibrates the node Fregatidae + Suloidea. 2, Rhynchaeites messelensis (SMF 218) from the middle Eocene of Messel. Together with other Messel Rhynchaeites messelensis specimens and Rhynchaeites sp. (MGUH 20288) from the early Eocene Fur Formation, these represent the sister taxon to Threskiornithidae, and MGUH 20288 calibrates the node uniting Threskiornithidae and its extant sister taxon. Scale bars equal $50 \mathrm{~mm}$.

(Livezey and Zusi, 2006, character 1914; Smith, 2010 , character 320 ); 3 ) a fibula that is at least $3 / 4$ the length of the tibiotarsus, but still does not reach its distal end (Livezey and Zusi, 2006, character 2191; convergently present in Podiceps within waterbirds); 4) a medially located sulcus extensorius on the distal tibiotarsus (Livezey and Zusi, 2006, character 2178); and 5) the relative distal extents of the trochleae metatarsals are II $<$ III $\geq$ IV, and II > IV (Livezey and Zusi, 2006, character 2361; Smith, 2010, character 445). Of these traits, characters $1,3,4$, and 5 are present in the calibrating specimen Rhynchaeites sp. MGUH 20288.

Minimum Age. 53.9 Ma

Soft Maximum Age. None specified.

Age Justification. The specimen was found by Peter Franz in the lower Eocene Fur Formation of northwest Denmark (Lindow and Dyke, 2006; Mayr and Bertelli, 2011). Nearly 180 layers of volcanic ash are interbedded within the Fur Formation (Egger and Brückl, 2006; Lindow and Dyke, 2006). The upper set of more closely spaced, black basaltic ash layers are numbered ranging from +1 to +140 in ascending stratigraphic order, whereas the lower set of more widely spaced, light colored layers are numbered from -1 to -39 in descending order (Bøggild, 1918; Egger and Brückl, 2006). Two ${ }^{39} \mathrm{Ar} / 40 \mathrm{Ar}$ radioisotopic dates have been reported from these ash layers, including a date of
$54.04+/-0.14 \mathrm{Ma}$ from layer +19 and a date of $54.52+/-0.05 \mathrm{Ma}$ from layer -17 (Chambers et al., 2003). More recently, a reanalysis of the ${ }^{39} \mathrm{Ar} / 40 \mathrm{Ar}$ radioisotopic dates from layer -17 produced an age of 55.12 +/- $0.12 \mathrm{Ma}$ (Storey et al., 2007), and adjusting this estimate based on the recalibration of the Fish Canton Tuff ( 28.201 Ma) sanidine reference standard (Kuiper et al., 2008) for ${ }^{39} \mathrm{Ar} /{ }^{40} \mathrm{Ar}$ radioisotopic dates yields a corrected age of 55.48 +/- 0.12 (Westerhold et al., 2009). Within the time period bounding layer -17 and +19 , approximately $0.5 \mathrm{~m}$ of volcanic ash and $19.5 \mathrm{~m}$ of diatomite were deposited (Bøggild, 1918; Egger and Brückl, 2006). However, the precise horizon from which MGUH 20288 was collected has not been reported, so whether these dates provide a minimum age, maximum age, or together bound the age of the fossils cannot be determined. With these considerations in mind, we apply the youngest possible age for MGUH 20288, inclusive of error: 53.9 Ma.

Phylogenetic position of Threskiornithidae and Rhynchaeites. Rhynchaeites messelensis (neotype SMF ME 1045; holotype specimen named by Wittich, 1898 has been lost, a neotype was designated by Peters, 1983) was the first fossil bird described from Messel, and was originally described as a member of Rostratulidae (Charadriiformes) by Wittich (1898). Hoch (1980) also sup- 
ported charadriiform affinities for the taxon. The threskiornithid affinities of Rhynchaeites messelensis were first noted by Peters (1983), and described in more detail by Mayr (2002a). The Fur Formation specimen of Rhynchaeites was previously described as a "pelecaniform" (Kristoffersen, 2002) and a galliform (Lindow, 2007) in two independent Ph.D. dissertations before being referred to Rhynchaeites by Mayr and Bertelli (2011). Mayr (2002a, 2009a), and Mayr and Bertelli (2011) discussed the threskiornithid features of Rhynchaeites in detail. The most salient apomorphies uniting Rhynchaeites with Threskiornithidae are an elongate recurved schizorhinal beak and a notarium consisting of at least three fused thoracic vertebrae (Mayr, 2002a, 2009a).

The extant sister-taxon relationships of Threskiornithidae have fluctuated considerably across morphological and molecular studies, though nearly all are consistent in recovering them as closely allied to various members of the traditional order Ciconiiformes. The main exceptions are the analysis of FGB-int7 sequences by Fain and Houde (2004), which recovered Threskiornithidae as sister taxon to Musophagidae; and the mitochondrial genome study of Brown et al. (2008), which recovered the aberrant sister-taxon relationship between Threskiornithidae and Musophagiformes. This clade was the sister taxon to a larger group including some Ciconiiformes, some Caprimulgiformes, and Apodiformes (Brown et al., 2008). Ericson et al. (2006) recovered Threskiornithidae in a basal polytomy with Ardeidae and a Pelecanidae + Balaenicipitidae + Scopidae clade; whereas Hackett et al. (2008) recovered a sister taxon relationship between Threskiornithidae and Ardeidae, with the Pelecanidae + Balaenicipitidae + Scopidae clade forming the sister taxon of this group. As for analyses of morphological data, Livezey and Zusi (2007) recovered the Threskiornithidae as sister taxon to a Ciconiidae + Phoenicopteridae clade, with this larger grouping as sister taxon to Scopidae. Smith (2010) recovered Threskiornithidae as part of a polytomy including Ardeidae and Ciconiidae, with this larger group constituting the sister taxon to Phoenicopteridae, though as noted by Smith (2010), support for various subgroups of Ciconiiformes was relatively low in this analysis. Similarly, Mayr (2011b) recovered a sister-taxon relationship between Threskiornithidae and Ciconiidae, with this group falling into large polytomy comprised of Ciconiiformes and Pelecaniformes.
Fossil record of total group Threskiornithidae. Rhynchaeites messelensis is one of the more abundant medium-sized birds known from the middle Eocene Messel locality, and is represented by more than a dozen partial to nearly complete specimens (Mayr and Bertelli, 2011; Smith et al., 2013). Other records that may pertain to total group Threskiornithidae of similar age include: 1) a distal tibiotarsus from the late middle Eocene of Myanmar referred to cf. Threskiornithidae by Stidham et al. (2005); 2) Vadaravis brownae, represented by a nearly complete postcranial skeleton from the early Eocene Green River Formation of Wyoming (Smith et al., 2013); 3) Eociconia sangequansis, represented by a distal left tarsometatarsus that may have Ciconiidae affinities, from the middle Eocene Yixibaila Formation of Xinjiang, China (Hou, 1982); and 4) Sanshuiornis zhangi, consisting of a distal tibiotarsus and complete articulated foot from the middle Eocene black oil shales of the Huayong Formation in Guangdong Province, southern China that shows affinities to Ciconiiformes, as well as Rhynchaeites messelensis (Wang et al., 2012). In most cases, these specimens are extremely fragmentary and their relationships have not been tested in a phylogenetic analysis; the exception being Vadaravis brownae, which was recovered as the sister taxon of a Ciconiidae + Phoenicopteridae + Threskiornithidae clade in a reanalysis of the Livezey and Zusi $(2006,2007)$ dataset by Smith et al. (2013). When the topological constraints of the Hackett et al. (2008) results for waterbird relationships were enforced, Vadaravis brownae was recovered as the sister taxon to Threskiornithidae (Smith et al., 2013). Potential younger members of total group Threskiornithidae (from the late Eocene onwards) are briefly reviewed by Smith et al. (2013), and likewise constitute fragmentary specimens whose relationships are contested and have not been tested in a phylogenetic analysis or justified with apomorphy-based diagnoses.

\section{STEM PELECANIDAE}

\section{Pelicans}

Node Calibrated. This node represents the split between Pelecanidae (monotypic family comprised of eight extant species of Pelecanus) and their extant sister taxon, which has been variable among molecular (Ericson et al., 2006; Hackett et al., 2008) and morphological (Livezey and Zusi, 2007; Smith, 2010; Mayr, 2011b) estimates of phylogeny.

Fossil Taxon. Pelecanus sp. 
Specimen. NT-LBR-039 (holotype; FSL-367.087 cast). A nearly complete skull and mandible, and several articulated cervical vertebrae.

Phylogenetic Justification. Phylogenetic justification is based on three cranial apomorphic characters of Pelecanidae that are preserved in the specimen (Louchart et al., 2011). These include a long, spatulate rostrum with two ridges on the ventral surface subparallel to the edges, long and thin mandibular rami, and a rostrally located syndesmotic intraramal hinge in the mandible. None of these characters are present in any other bird species, thus they will optimize as synapomorphies uniting NT-LBR-039 and extant pelicans regardless of which avian group constitutes the extant sister taxon of Pelecanidae.

Minimum Age. 28.1 Ma

Soft Maximum Age. None specified.

Age Justification. The specimen was collected from Pichovet, $3 \mathrm{~km}$ northeast of Vachéres, Luberon, in southeastern France $\left(43^{\circ} 55^{\prime} \mathrm{N}, 5^{\circ} 40^{\prime} \mathrm{E}\right)$ (Louchart et al., 2011). The specimen was found in fine-grained limestone, indicative of a coastal freshwater lagoon depositional environment (Louchart et al., 2011). The deposits from Pichovet have been biostratigraphically correlated with the Mammal Paleogene biostratigraphic zone MP 24, which is within the Rupelian (Mourer-Chauviré, 1985; Legendre and Lévêque, 1997; Mayr, 2006). The temporal age range for the Rupelian has been inferred to be 28.1-33.9 Ma (BiochroM, 1997; Gradstein et al., 2012; Cohen et al., 2013; Walker et al., 2013). Following best practices for justifying minimum age constraints (Parham et al., 2012), we apply the youngest possible age for the Rupelian, inclusive of error: $28.1 \mathrm{Ma}$.

Phylogenetic position of Pelecanidae and the Oligocene Pelecanus sp. Traditional taxonomy and phylogenetic studies based on morphological data (Cracraft, 1985; Livezey and Zusi, 2007 and references therein) have suggested the Pelecanidae are sister-taxon to Suloidea (Sulidae, Anhingidae, Phalacrocoracidae), with this larger group constituting the sister taxon to Fregatidae. This group of "pelecaniforms" exclusive of tropicbirds (Phaethontidae) is known as Steganopodes (Chandler, 1916). The study of Smith (2010) also recovered a monophyletic Steganopodes, but with Fregatidae as the sister taxon to Suloidea and Pelecanidae as the successive sister taxon to this clade. However, Mayr (2011b) recovered a Pelecanidae + Balaenicipitidae clade that is sister taxon to Scopidae, with this larger group in a basal polytomy with other clades of Ciconiiformes and Pele- caniformes. Mayr's (2011b) result is more similar to the topologies that have long been recovered by molecular studies. Van Tuinen et al. (2001) provided some of the first molecular support for a Pelecanus + Balaeniceps + Scopus clade, and subsequent studies with more taxon-sampling and diverse genetic data have largely confirmed this grouping (Fain and Houde, 2004; Ericson et al., 2006; Hackett et al., 2008). Thus, the relative utility of the Oligocene Pelecanus sp. (NT-LBR-039) as a fossil calibration is highly dependent on the topology of the phylogeny being temporally calibrated (e.g., it would represent the oldest record of a Pelecanus + Balaeniceps + Scopus clade, but not the oldest record of a monophyletic Steganopodes).

Fossil record of total group Pelecanidae. Protopelicanus cuvieri, represented by an isolated femur from the late Eocene Paris Gypsum of France, has previously been considered to share affinities with pelicans, sulids, and pelagornithids, but as Mayr (2009a, p. 80) notes, the affinities of this material should be considered indeterminate until more complete remains and/or apomorphybased diagnoses can be advanced. Beyond NTLBR-039, the next oldest fossil stem Pelecanidae is Miopelecanus gracilis from the early Miocene of France, which is represented by a cranium and caudal portion of the rostrum (Olson, 1985). Louchart et al. (2011) suggested that this taxon might be referable to Pelecanus. However, regardless of this taxonomic uncertainty, there is currently no evidence to support the phylogenetic placement of either NT-LBR-039 or Miopelecanus gracilis within crown pelicans (e.g., crown Pelecanidae/crown Pelecanus). Other Neogene and Quaternary records of total group Pelecanidae are limited, but members of the clade are known from all continents, with the exception of Antarctica (Stidham et al., 2014).

Based on the topologies of most higher-level avian phylogenies based on molecular data (e.g., Ericson et al., 2006; Hackett et al., 2008), NT-LBR039 would calibrate splits within a Pelecanus + Balaeniceps + Scopus clade. The oldest member of total group Balaenicipitidae is Goliathia andrewsi from the early Oligocene lower sequence of the Jebel Qatrani Formation of Egypt (Brodkorb, 1980; Rasmussen et al., 1987). The holotype of Goliathia andrewsi is a complete ulna (NHMUK A883), and a distal end of a right tarsometatarsus lacking the trochleae from the upper sequence of the Jebal Qatrani Formation has also been referred to this species (Rasmussen et al., 1987; Smith, 2013, figure 3). Scopus xenopus, represented by a distal 
tarsometatarsus and partial coracoid from the early Pliocene of South Africa, constitutes the only known fossil record of total group Scopidae (Olson, 1984). Neither Goliathia andrewsi nor Scopus xenopus have been evaluated in a phylogenetic analysis.

Based on the topologies recovered from most morphological studies, NT-LBR-039 would either calibrate the split between Pelecanidae and a Fregatidae + Suloidea clade (Smith, 2010); or between Pelecanidae and Suloidea (Cracraft, 1985; Livezey and Zusi, 2007). In the former case, NT-LBR-039 would be superseded as a fossil calibration by the older stem-frigatebird Limnofregata (Smith, 2010; see below). In the latter cases, there are several potentially older members of total group Suloidea that might supersede NT-LBR-039. These include (but are not limited to): 1) Masillastega rectirostris from the middle Eocene of Messel, an isolated skull that may be a stem member of Sulidae (Mayr, 2002b); 2) Eostega lebedinskyi from the middle Eocene of Romania, an incomplete mandible that may also be a stem sulid and/or a senior synonym of Masillastega (Mlíkovsky, 2002, 2007; Mayr, 2009a); 3) Phocavis maritimus, represented by a tarsometatarsus from the late Eocene to early Oligocene Keasey Formation of northwest Oregon (Goedert, 1988) and a member of the extinct Plotopteridae, which may constitute the sister taxon to a Phalacrocoracidae + Anhingidae clade (Smith, 2010); and 4) the enigmatic Protoplotus beauforti, a nearly complete skeleton from lacustrine sediments of Sumatra (likely Paleocene in age; Whateley and Jordon, 1989), that has been allied with various members of the Pelecaniformes (van Tets et al., 1989; Smith, 2010). With the exception of Protoplotus, most of these specimens are represented by fragmentary or incomplete material; and in all cases, their relationships among extant groups of waterbirds have remained controversial, and have not been tested in phylogenetic analyses.

\section{STEM FREGATIDAE}

\section{Frigatebirds}

Node Calibrated. This node represents the split between Fregatidae and their extant sister taxon, the Suloidea (including Sulidae, Phalacrocoracidae, and Anhingidae). Phylogenetic analyses of both molecular (Ericson et al., 2006; Hackett et al., 2008) and morphological (Smith, 2010; Mayr, 2011b) data support a sister-taxon relationship between Fregatidae and Suloidea.
Fossil Taxon. Limnofregata Olson, 1977

Specimen. USNM 22753 (holotype of Limnofregata azygosternon; Figure 1.1). Additional support for this calibration is provided by contemporaneous specimens of this species including UWGM 6919 (paratype); GMNH PV 167 (referred specimen from four meters above the "18 inch layer") and of the species Limnofregata hasegawai including GMNH PV 170 (holotype; collected 2-3 meters laterally from GMNH PV 167); FMNH PA 719 (referred specimen from Thomson Ranch, F-2 Facies). A new species of Limnofregata, UCMP 134932, represented by an articulated right coracoid and humerus recovered from UCMP locality V70272 in the Wasatch Formation of Wyoming, also provides additional support for this calibration (Stidham, 2015).

Phylogenetic Justification. Phylogenetic justification is based on analyses of osteological data from Smith (2010). The analysis of Smith (2010) recovered 18 unambiguous synapomorphies of a Limnofregata + Fregata clade, with six of these exhibiting no homoplasy on the most-parsimonious trees. Synapomorphies include cranial, axial, pectoral, and pelvic characters distributed throughout the skeleton. The synapomorphies supporting a Limnofregata + Fregata clade, presented in the format: "Character(character state)", with boldface indicating no homoplasy in the character on the most-parsimonious trees, include: 30(1) Quadrate, shape of otic head in dorsal aspect: compressed anteroposteriorly and distinctly elongate mediolaterally; 101(1) Number of cervical vertebrae: 15 or 16 ; 102(1) Osseous bridge from processus transversus to processus articularis caudalis on third cervical vertebra: present; 103(0) Cervical vertebrae 8-11 with processus carotici ankylosed along the midline, forming an osseous canal: no; 108(1) Sternum, shape and relative craniocaudal length to mediolateral width of dorsal surface of sternal body: square-shaped, sternal body wider than long; 114(2) Number of costal facets on sternum: six; 133(2) Sternum, relative convexity of ventral carinal margin in lateral aspect: extremely convex, approaching semicircular profile; 134(0) Sternum, apex carinae of sternum pointed and projecting far rostrally to coracoid sulci: no; 155(0) Scapula, relative cranial extension of acromion: short, does not extend cranial to articular facies for the coracoid; 201(2) Humerus, tuberculum $\mathrm{m}$. pectoralis superficialis, pars deep depth: deep groove medial and distal to tuberculum, with distal portion of tuberculum hypertrophied as a round swelling; 206(1) Humerus, relative development and shape of delto- 
pectoral crest: strongly protruding and triangular; 221(2) Humerus, shape of tuberculum supracondylare ventrale in medial (ventral aspect): distal half of tuberculum distinctly concave, giving the tuberculum a triangular, 'pointed' appearance in medial (ventral) aspect; 223(2) Humerus, relative location of muscle scar for insertion of $\mathrm{M}$. pronator superficialis (= "m. pronator brevis"): only slightly posterior, and proximal to tuberculum supracondylare ventrale; 293(1) Manus, proximodistally elongate fenestra on the distal third of the blade of II-1: present; 316(1) Pelvis, interacetabular width relative to synsacral length: between $1 / 2$ to $1 / 3 ; 394(1)$ Tibiotarsus, medial ridge of trochlea cartilaginis tibialis hypertrophied, robust, and mound-like: present; 404(1) Tarsometatarsus, proximodistal length of tarsometatarsus relative to the femur: short, tarsometatarsus less than $1 / 2$ of the length of the femur; 408(2) Tarsometatarsus, development and orientation of eminentia intercondylaris (= "intercotylar prominence"): short, and rounded, weakly developed with no dorsal component. See Smith (2010) for full descriptions of characters and states, as well as original sources for characters.

Synapomorphies of the Limnofregata + Fregata clade that are present in UCMP 134932 include: characters 201(2), 221(2), and 223(2). Breakage of the deltopectoral crest of UCMP 134932 prevents assessment of character 206. The presence of several plesiomorphic (relative to crown frigatebirds) features in UCMP including: 144(0) Claviculae, fenestra (fenestra subacrocoracoidea claviculae) created by fusion of anterodorsal portion of processus omalis claviculae to coracoid: absent; and 219(0) Humerus, fossa olecrani pneumaticity: absent or extremely small pneumatic foramina scattered on surface; indicate its position outside of Fregatidae (Smith, 2010; Stidham, 2015).

Minimum Age. $51.81 \mathrm{Ma}$

Soft Maximum Age. None specified.

Age Justification. Both the holotype (USNM 22753; Figure 1.1) and referred specimen (UWGM 6919) of Limnofregata azygosternon were collected near Kemmerer in Lincoln County, Wyoming. Their exact locality data is not known, though more precise locality data is known for several referred specimens as well as the holotype and referred specimens of Limnofregata hasegawai (see "Specimens" section above). These specimens are from the F-2 Facies, in the middle unit of the Fossil Butte Member of the Green River Formation (Grande and Buchheim, 1994; Grande, 2013). These deposits are late early Eocene, and multicrystal analyses (sanidine) from a K-feldspar tuff (FQ-1) at the top of the middle unit of the Fossil Butte Member, from Fossil-Fowkes Basin (locality: $\left.\mathrm{N} 41^{\circ} 47^{\prime} 32.2^{\prime \prime} \mathrm{W} 110^{\circ} 42^{\prime} 39.6^{\prime \prime}\right)$ have yielded an age of $51.97 \pm 0.16 \mathrm{Ma}$ (Smith et al., 2010).

UCMP locality V70272, where specimen UCMP 134932 was recovered, is located in Sweetwater County, Wyoming. The specific locality is from Bitter Creek 22 Level 3, which is a lignite bed in the Main Body of the Wasatch Formation (Stidham, 2015). Mammal fossils from Bitter Creek have been interpreted as Graybullian, roughly corresponding to the Wasatchian North American Land Mammal Age (NAMLA 3-5 subzones of the Bighorn Basin) (Stidham, 2015). UCMP V70272 is also stratigraphically below Bitter Creek fossil lizard localities considered to represent the Wasatchian subzones late Wa4-Wa6 (Smith and Gauthier, 2013; Stidham, 2015), suggesting that these Limnofregata specimens are from an equivalent of the early Wa4 or older subzone. Current estimates for the age of the Graybullian (Wa3Wa5) range from 53.9 to $55.1 \mathrm{Ma}$ (Chew and Oheim, 2013; Gradstein et al., 2012; Stidham, 2015). Although the evidence for UCMP 134932 being located stratigraphically below other Limnofregata specimens (and the possibility that it may be $\sim 2$ million years older than these fossils) is compelling, no direct radiometric dates are associated with this specimen and locality, necessitating a cross-basin correlation using mammal biostratigraphy (Stidham, 2015). For these reasons, the hard minimum age of UCMP 134932 would actually be younger than the minimum age that can be established for the Green River Formation Limnofregata specimens.

Phylogenetic position of Fregatidae and Limnofregata. Limnofregata azygosternon (Figure 1.1) was originally described as a stem-frigatebird by Olson (1977) and placed in the monotypic genus Limnofregata, and monotypic subfamily Limnofregatinae, within the Fregatidae. An additional species, Limnofregata hasegawai, was subsequently described in 2005 , differing only in overall size and several skeletal proportions from L. azygosternon (Olson and Matsuoka, 2005). The inferred close relationship between Limnofregata and Fregata has never been challenged, though Mayr (2005) noted similarities between Limnofregata and the plotopterid Phocavis maritimus (Goedert, 1988), represented by a single tarsometatarsus. However, the analyses of Smith (2010) represented the first rigorous tests of the phylogenetic relationships of Limnofregata, recov- 
ering it as the sister-taxon to Fregata with strong support.

The extant sister-taxon of Fregata has been slightly more contentious. Most traditional taxonomies and studies of morphological data suggested that Fregata represented the sister-taxon to a Pelecanus + Suloidea (Sulidae, Phalacrocoracidae, Anhingidae) clade (Livezey and Zusi, 2007 and references therein). However, more recent morphological (Smith, 2010; Mayr, 2011b) and molecular datasets (Fain and Houde, 2004; Ericson et al., 2006; Hackett et al., 2008) are consistent in recovering a sister-taxon relationship between Fregatidae and Suloidea. Additionally, molecular datasets have long contradicted a sister-taxon relationship between Pelecanus and Suloidea, typically recovering the former as closely related to the shoebill, Balaeniceps, and the hammerkop, Scopus (van Tuinen et al., 2001; Ericson et al., 2006; Hackett et al., 2008). More recently, morphological support has also been described for a clade uniting Pelecanus, Balaeniceps, and Scopus (Mayr, 2011b).

Fossil record of total group Fregatidae. The fossil record of total group Fregatidae is extremely depauperate, with multiple specimens from the three known species of Limnofregata representing the only Pre-Quaternary records (Olson, 1985; Smith, 2010; Stidham, 2015). The Quaternary records are all from oceanic islands and can all be referred to extant species of Fregata (Olson, 1985). Thus, we have little evidence to support a maximum age for this clade.

\section{STEM PHALACROCORACIDAE}

\section{Cormorants and Shags}

Node Calibrated. This node represents the split between Phalacrocoracidae and their extant sister taxon, the Anhingidae. Phylogenetic analyses of both molecular (Ericson et al., 2006; Hackett et al., 2008) and morphological (Livezey and Zusi, 2006, 2007; Smith, 2010; Mayr, 2011b) data strongly support a sister-taxon relationship between Phalacrocoracidae and Anhingidae.

Fossil Taxa. ?Borvocarbo stoeffelensis Mayr (2007)

Specimen. PW 2005/5022-LS (holotype). The holotype consists of a slightly dissociated, but still largely articulated, specimen, missing several vertebrae, the pelvis, and most of the left foot (Mayr, 2007). The original description (Mayr, 2007, p. 931) notes that while the specimen is currently reposited in Landesamt für Denkmalpflege Rheinland-Pfalz, Mainz, Germany, it will eventually be transferred to the Landessammlung für Naturkunde, Mainz, Germany.

Phylogenetic Justification. Phylogenetic justification is based on analyses of osteological data from Smith (2010). The analysis of Smith (2010) recovered three unambiguous synapomorphies of a ?Borvocarbo stoeffelensis + Phalacrocoracidae clade, one of which exhibits no homoplasy on the most-parsimonious trees. Synapomorphies are represented in the mandible and pes of the skeleton. The synapomorphies supporting a ?Borvocarbo stoeffelensis + Phalacrocoracidae clade, presented in the format: "Character(character state)", with boldface indicating no homoplasy in the character on the most-parsimonious trees, are: 91(1) Mandible, surangular, area at posteromedial attachment of $M$. adductus mandibulae externus profundus: presence of a single robust, knob-like tuberosity; 446(2) Pes, relative lengths of digits III and IV: digit IV significantly longer than digit III, often by nearly the entire distal phalanx of digit IV; 464(1) Pes, strong dorsoventral compression of phalanges of pes: present. In addition, there are two characters described by Mayr (2007) as suggestive of a close relationship between ?Borvocarbo stoeffelensis and Phalacrocoracidae that were not included in the phylogenetic analysis of Smith (2010). These are a well-developed crista nuchalis sagittalis along the midline of the skull (absent in 'microcormorants') and an accessory transverse cranial crest present caudal to crista nuchalis transversa.

Minimum Age. 24.52 Ma

Soft Maximum Age. None specified.

Age Justification. The holotype of ?Borvocarbo stoeffelensis was recovered from the fossil Lagerstätte Enspel, near Bad Marienberg in Westerwald, Rheinland-Pfalz, Germany. The Enspel deposits correspond to the upper Oligocene Mammal Paleogene reference level 28 (Mertz et al., 2007). Laser fusion ${ }^{40} \mathrm{Ar} /{ }^{39} \mathrm{Ar}$ radiometric dating of volcanic feldspars from the lower and upper basaltic flows that bound the Enspel lacustrine deposits yielded ages of $24.56 \pm 0.04$ to $24.79 \pm 0.05 \mathrm{Ma}$ (Mertz et al., 2007).

Phylogenetic position of total group Phalacrocoracidae and ?Borvocarbo stoeffelensis. Mayr (2001) originally described a partial right foot, tarsometatarsus, and distal tibiotarsus to ?Oligocorax $\mathrm{sp}$. This specimen was later referred to ?Borvocarbo stoeffelensis when this new taxon was erected by Mayr (2007). Although Mayr (2007, $2009 \mathrm{~b})$ has suggested that some of the characters supporting a ?Borvocarbo stoeffelensis + Phala- 
crocoracidae could represent deeper synapomorphies of Phalacrocoracoidea (Phalacrocoracidae + Anhingidae) that are later lost in anhingas, the only phylogenetic analysis that has tested the relationships of ?Borvocarbo stoeffelensis recovered it as the sister taxon to Phalacrocoracidae with fairly strong support (Smith 2010). Both morphological (Cracraft, 1985; Bourdon et al., 2005; Livezey and Zusi, 2007; Smith, 2010) and molecular (Ericson et al., 2006; Brown et al., 2008; Hackett et al., 2008) analyses have been consistent in recovering strong support for a Phalacrocoracidae + Anhingidae clade. The primary exceptions to this are the nuclear dataset based on intron 7 of the $\beta$-fibrinogen gene from Fain and Houde (2004) and the mitochondrial dataset of Kennedy et al. (2005), which both recover the aberrant grouping of Sulidae + Anhingidae, a result that may be due in part to long-branch attraction (Kennedy et al., 2005).

Fossil record of total group Phalacrocoracidae and ?Borvocarbo stoeffelensis. Potential older members of total group Phalacrocoracidae include Piscator tenuirostris, represented by a rostral section of the upper mandible and described by Harrison and Walker (1976b) as a cormorant; as well as a partial premaxilla from the early Oligocene Jebel Qatrani Formation of Egypt that was referred to the Phalacrocoracidae by Rasmussen et al. (1987). There are also undescribed cormorant-like specimens from the Eocene-Oligocene Quercy fissure fillings in France (Mourer-Chauviré, 1982), and from the early Oligocene of Céreste, France (Roux, 2002; Mayr, 2007), that have been suggested as representing the family. However, in most cases, these specimens are represented by extremely fragmentary material, and in all cases, their relationships have not been evaluated in a phylogenetic analysis.

The recently described Anhinga walterbolesi, a tarsometatarsus from the late Oligocene-early Miocene Etadunna Formation of South Australia, likely represents the oldest stem-member of Anhingidae (Worthy, 2012). This specimen has the potential to be older than ?Borvocarbo stoeffelensis. However, the referral of the type locality of Anhinga walterbolesi to the Etadunna Formation is based on the presence of the duck Pinpanetta tedfordi in these deposits, and the Etadunna Formation itself currently has an age range of 24-26 Ma, based on biostratigraphic and magnetostratigraphic data (Woodburne et al., 1994), making the minimum possible age younger than that for ?Borvocarbo stoeffelensis. It is worth noting however, that this still suggests the oldest records for stem
Phalacrocoracidae and stem Anhingidae occur close to the same time.

\section{DISCUSSION}

\section{Waterbird Phylogenetic Relationships and Temporal Diversification}

We consider the results of the phylogenomic analysis of Hackett et al. (2008; see also McCormack et al., 2013 for congruent results, albeit with a smaller sample of waterbird taxa) as the best current estimate of higher-level relationships within the waterbird assemblage. This topology, and the phylogenetic relationships of the five fossil calibrations discussed above, is displayed in Figure 2. An alternative waterbird phylogeny based on an analysis of osteological data by Smith (2010), which was also used to establish the relationships of most of the fossil calibrations discussed here, is displayed in Figure 3. These two exemplars highlight some of the current conflict regarding waterbird phylogeny regarding interfamilial relationships, as well as support (or lack thereof) for monophyly of traditional avian orders within the group. It is worth noting that these conflicts do not represent a fundamental dichotomy between morphological and molecular datasets, as disagreement between estimates of waterbird relationships exists within these two classes of data as well (Cracraft, 1985; Fain and Houde, 2004; Ericson et al., 2006; van Tuinen et al., 2006; Livezey and Zusi, 2007; Brown et al., 2008; Hackett et al., 2008; Smith, 2010; Mayr, 2011b; McCormack et al., 2013).

Given this phylogenetic uncertainty, one of the most important aspects of establishing future vetted fossil calibrations within the waterbird assemblage will be robustly establishing the phylogenetic position of fossils, and demonstrating that the sister taxon relationships of these fossil calibrations are invariant across different estimates of topological relationships (i.e., criterion 3 of Parham et al., 2012; see also Smith, 2010). What is evident regardless of phylogenetic uncertainty is that most major lineages within the waterbird assemblage had diverged by the Eocene (Figures 2, 3), and that many of the major body plans and ecomorphotypes characteristic of extant members of the clade may have been established by this time (Ksepka and Clarke, 2010; Smith, 2010; Louchart et al., 2011; Smith et al., 2013). The fact that oldest members of most waterbird lineages are Paleogene in age, with records of purported Cretaceous members questionable (see below), also lends support to traditional paleontological perspectives on the 


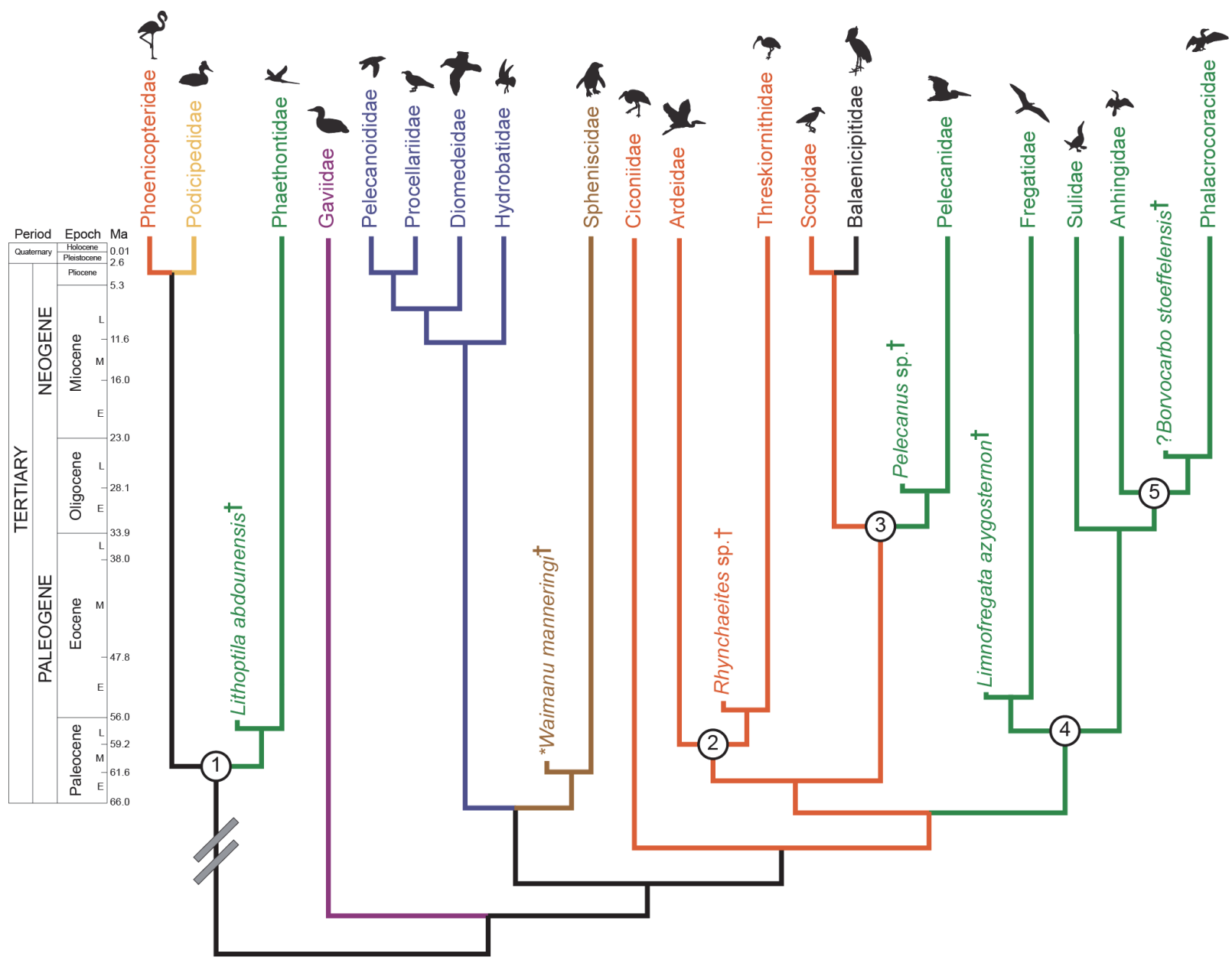

FIGURE 2. Preferred phylogenetic tree based on the phylogenomic analysis of Hackett et al. (2008) showing the family-level relationships (with silhouettes of representatives within each family) within the waterbird assemblage, with five fossil calibrations (Table 1) included. Groups color-coded by membership in traditional avian orders: Pelecaniformes (green), Ciconiiformes (orange), Procellariiformes (blue), Sphenisciformes (brown), Podicipediformes (gold), Gaviiformes (purple). Stratigraphy and associated ages from Cohen et al. (2013; see also Walker et al., 2013). Branches (internodes) outside of fossil calibrations are set to a unit length to make topological relationships clear, and are not intended to represent actual divergence times. Double hash marks indicate that the clade containing Phaethon, Podiceps, and Phoenicopterus is actually recovered as distantly related to the waterbird clade (i.e., it is not its sister-taxon). Nodes that are numbered correspond to fossil calibrations described in the text. Asterisk next to Waimanu manneringi references a vetted calibration from Ksepka and Clarke (2015). Abbreviations: E, Early. M, Middle. L, Late.

timing of the crown radiation of birds, which emphasize this as being a post-Cretaceous event (Feduccia, 1995; Mayr, 2009a; Longrich et al., 2011).

\section{Other Calibrations within the Waterbird Assemblage}

The oldest representative of total group Sphenisciformes (penguins) currently recognized is Waimanu manneringi, represented by an associated partial postcranial skeleton from the late early Paleocene of New Zealand (Slack et al., 2006). Calcareous nannofossils imply an age of 60.5-61.6
Ma for Waimanu manneringi (Slack et al., 2006). Phylogenetic support for the placement of Waimanu manneringi and its congener Waimanu tuatahi as the basal-most members of Sphenisciformes is particularly strong (Slack et al., 2006; Ksepka and Clarke, 2010, 2015). Coupled with its late early Paleocene age, this makes Waimanu manneringi particularly useful as a robust fossil calibration for studies of waterbird, and higher-level avian, temporal diversification (Slack et al., 2006; Ho and Phillips, 2009; Smith, 2010; Smith et al., 2013; Ksepka and Clarke, 2015). 


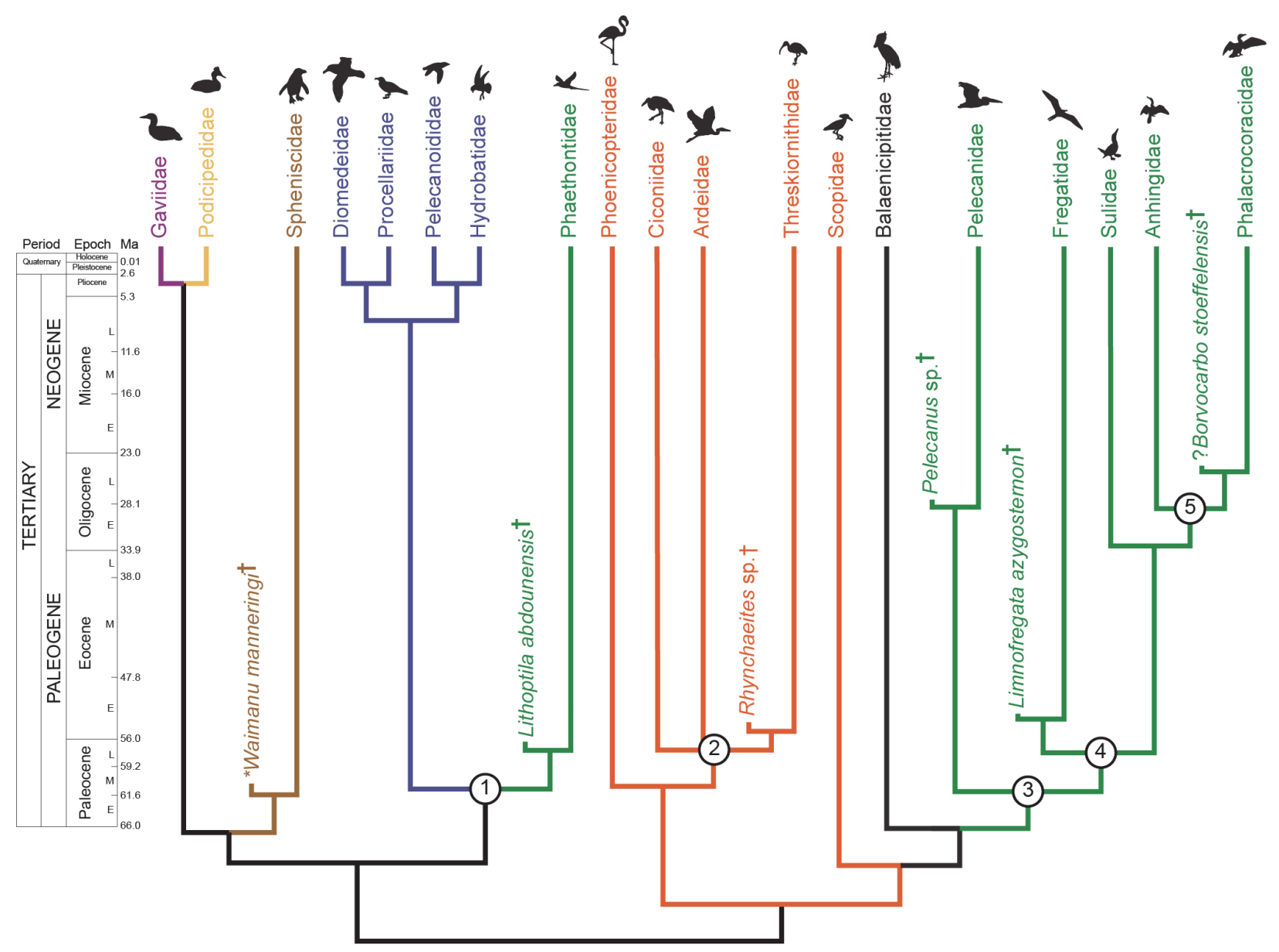

FIGURE 3. Alternative phylogenetic tree based on the osteological analysis of Smith (2010) showing the family-level relationships (with silhouettes of representatives within each family) within the waterbird assemblage, with five fossil calibrations (Table 1) included. Groups color-coded by membership in traditional avian orders: Pelecaniformes (green), Ciconiiformes (orange), Procellariiformes (blue), Sphenisciformes (brown), Podicipediformes (gold), Gaviiformes (purple). Stratigraphy and associated ages from Cohen et al. (2013; see also Walker et al., 2013). Branches (internodes) outside of fossil calibrations are set to a unit length to make topological relationships clear, and are not intended to represent actual divergence times. Nodes that are numbered correspond to fossil calibrations described in the text. Asterisk next to Waimanu manneringi references a vetted calibration from Ksepka and Clarke (2015). Abbreviations: E, Early. M, Middle. L, Late.

Gaviiformes includes some purported stem members from the Cretaceous, such as Neogaeornis wetzeli, represented by an isolated tarsometatarsus from the Campanian/Maastrichtian of Chile (Olson, 1992), and Polarornis gregorii, a partial skeleton including some cranial material from the Late Cretaceous of Antarctica (Chatterjee, 2002). The gaviiform affinities of both these specimens have been questioned (Mayr, 2004; Mayr and Poschmann, 2009; Smith, 2010; Mayr et al., 2013), and Mayr et al. (2013) noted the large discrepancy in morphology between putative Late Cretaceous gaviiform taxa and those from the early Paleogene. The next-oldest records of stem Gaviiformes are
Colmbiculus udovichenkoi from the middle Eocene of Ukraine (Mayr and Zvonok, 2011; Mayr et al., 2013) and Colymboides anglicus from the late Eocene of England (Lydekker, 1891; Storer, 1956, Harrison and Walker, 1976b). More complete skeletal material referable to Gaviiformes is known from the early Oligocene (Mayr, 2004, 2009c; Smith, 2010). In most cases, the relationships of these purported stem members of Gaviiformes remain to be assessed in a phylogenetic analysis, and controversy still surrounds the taxonomic assignments of the oldest purported records (Smith, 2010; Mayr et al., 2013). 
With regard to other potential fossil calibrations within Ciconiiformes, most of the potential oldest records are fairly controversial, fragmentary, and untested in phylogenetic analyses and/or unjustified by apomorphy-based diagnoses (Smith et al., 2013). The monophyly and interrelationships of Ciconiiformes are also highly variable across various estimates of waterbird phylogeny (Fain and Houde, 2004; Ericson et al., 2006; Livezey and Zusi, 2007; Brown et al., 2008; Hackett et al., 2008; Smith, 2010; Mayr, 2011b), which warrants caution in applying un-vetted fossil calibrations within the group. Indeed, most molecular studies recover flamingos distantly related to other Ciconiiformes and waterbirds, as the well-supported sister taxon to grebes (Fain and Houde, 2004; Ericson et al., 2006; Hackett et al., 2008). Previous analyses have used the early Oligocene stem flamingo Adelalopus hoogbutseliensis (Mayr and Smith, $2002 b$ ) to calibrate the grebe-flamingo split (Ericson et al., 2006; Torres et al., 2014), and undescribed early Oligocene grebes have also been referenced in the literature (Ksepka et al., 2013; Mayr, 2014). Also, regardless of the exact phylogenetic position of Threskiornithidae in different morphological and molecular analyses (Fain and Houde, 2004; Ericson et al., 2006; Livezey and Zusi, 2007; Brown et al., 2008; Hackett et al., 2008; Smith, 2010; Mayr, 2011b), most of these analyses are consistent in recovering Threskiornithidae as deeply nested within other groups of the traditional orders Ciconiiformes and Pelecaniformes. Thus, the stem Threskiornithidae calibration provided by Rhynchaeites would make additional calibrations for more deeper nodes within this group unnecessary for calibrating minimum times of divergence (though note that such calibrations may still be very useful for divergence time estimation methods that jointly estimate phylogeny and temporal splits; see e.g., Heath, 2012; Ronquist et al., 2012).

The oldest purported record of Procellariiformes is Tytthostonyx glauconiticus, a nearly complete right humerus from the Late Cretaceous or early Paleocene Hornerstown Formation of New Jersey (Olson and Parris, 1987). However, both Olson and Parris in their original description (1987), as well as Bourdon et al. (2008), have questioned this referral, noting that this taxon also shows similarities to Charadriiformes and Pelecaniformes. A variety of fragmentary specimens from the Eocene have been referred to extant procellariiform families, with more complete material known from the early Oligocene, but none of these have been evaluated in a phylogenetic analysis or with rigorous apomorphy-based diagnoses (Smith, 2010). Additionally, the large amount of discrepancy between morphological (e.g., Bourdon et al., 2005; Livezey and Zusi, 2007; Smith, 2010) and molecular (e.g., Nunn and Stanley, 1998; Kennedy and Page, 2002; Ericson et al., 2006; Brown et al., 2008; Hackett et al., 2008) datasets regarding the interfamilial relationships of Procellariiformes, suggests that utilizing fossil calibrations within this group based on the existing taxonomic assignment of fossil specimens may be premature, or at the least, requires a robust demonstration of the invariant position of a purported fossil calibration across different estimates of topological relationships (i.e., criterion 3 of Parham et al., 2012).

\section{CONCLUSIONS}

Understanding the temporal diversification of the waterbird clade is critical to placing broader questions regarding their evolutionary history into context, whether they are analyses of lineage diversification (van Tuinen et al., 2006; Brown et al., 2008; Pacheco et al., 2011; Haddrath and Baker, 2012; Jetz et al., 2012); trait evolution (Nunn and Stanley, 1998; Simons et al., 2011; Smith, 2012; Felice and O'Connor, 2014); ecology (Gibb et al., 2013); or biogeography (Friesen and Anderson, 1997; Ksepka and Thomas, 2012). We vetted the phylogenetic placement and geochronological context of five well-supported fossil calibrations from the waterbird assemblage that will provide robust temporal calibrations for the origins of: stem Phaethontes (tropicbirds); stem Threskiornithidae (ibises and spoonbills); stem Pelecanidae (pelicans); stem Fregatidae (frigatebirds); and stem Phalacrocoracidae (cormorants). This is not an exhaustive review of potential waterbird fossil calibrations, but rather an emphasis on those that are currently among the most robustly supported, based on the criteria of Parham et al. (2012), and the most potentially useful for analyses of temporal diversification within the group. It is our hope that continued review of the waterbird fossil record and new analyses and syntheses of waterbird phylogenetic relationships will yield additional, well-vetted fossil calibrations within the clade.

\section{NOTE ADDED IN PROOF}

A recently published paper (Mayr, 2015b), describes a new specimen of stem-cormorant, PW 2013/5000-LS, that represents the same taxon as PW2005/5022-LS. Mayr (2015b) revises the taxonomy of this species from ?Borvocarbo stoeffelensis 
to Oligocorax stoeffelensis. However, this new record does not alter the inferred phylogenetic position of this taxon as a stem-cormorant (calibrating the Anhingidae-Phalacrocoracidae split), nor does it alter the temporal age assigned to this taxon.

\section{ACKNOWLEDGMENTS}

For access to collections, we thank the following people: B. Breithaupt, T. Chesser, J. Dean, R. Eng, R. Faucett, M. Florence, L. Grande, M. Hennen, P. Holroyd, H. James, S. Olson, P. Scofield, C. Sidor, B. Simpson, P. Tubaro, D. Willard, and C. Wood. We are indebted to T. Stidham for providing access to his in press manuscript describing new Limnofregata material. This manuscript also benefited from the comments of Palaeontologia Electronica editor P. David Polly and three anonymous reviewers. We also thank R. Irmis and J. Parham for support and discussion. This research was supported by the Field Museum of Natural History Brown Family Graduate Fellowship, NSF DEB0808250, and NSF DEB-1331980 to N.D. Smith, a Postdoctoral Fellowship to D.T. Ksepka supported by the National Evolutionary Synthesis Center (NESCent), NSF EF-0423641, and the NESCent Synthesizing and Databasing Fossil Calibrations Working Group (NSF EF-0905606).

\section{REFERENCES}

Andrews, C.W. 1899. On the remains of a new bird from the London Clay of Sheppey. Proceedings of the Zoological Society of London, 1899:776-785.

Bell, C.J., Head, J.J., and Mead, J.I. 2004. Synopsis of the herpetofauna from Porcupine Cave, p. 117-126. In: Barnosky, A.D. (ed.), Biodiversity Response to Climate Change in the Middle Pleistocene: The Porcupine Cave Fauna from Colorado. University of Berkeley Press, Berkeley, CA, USA.

Benton, M.J. and Donoghue, P.C.J. 2007. Paleontological evidence to date the Tree of Life. Molecular Biology and Evolution, 24:26-53.

Bever, G.S. 2005. Variation in the ilium of North American Bufo (Lissamphibia; Anura) and its implications for species-level identification of fragmentary anuran fossils. Journal of Vertebrate Paleontology, 25:548560.

BiochroM'97. 1997. Synthése et tableaux de corrélations, p. 769-805. In: Aguilar, J.-P., Legendre, S., and Michaux, J. (eds.), Actes du Congrès BiochroM'97. Mémoires et Travaux de l'École Pratique des Hautes Études, Institut de Montpellier 2, France.

Bøggild, O.B. 1918. Den vulkanske Aske i Moleret samt en Oversigt over Danmarks aeldre Tertiaerbjaergarter. Danmarks Geologiske Undersøgelse (Series 2), 33:1-159.
Bourdon, E., Bouya, B., and larochene, M. 2005. Earliest African neornithine bird: A new species of Prophaethontidae (Aves) from the Paleocene of Morocco. Journal of Vertebrate Paleontology, 25:157-170.

Bourdon, E., Mourer-Chauviré, C., Amaghzaz, M., and Bouya, B. 2008. New specimens of Lithoptila abdounensis (Aves, Prophaethontidae) from the Lower Paleogene of Morocco. Journal of Vertebrate Paleontology, 28:751-761.

Brodkorb, P. 1980. A new fossil heron (Aves: Ardeidae) from the Omo Basin of Ethiopia, with remarks on the position of some other species assigned to the Ardeidae. p. 87-92. In Campbell, K.E. (ed.), Papers in Avian Paleontology Honoring Hildegarde Howard. Natural History Museum of Los Angeles County Contributions in Science, 330.

Brown, J.W., Rest, J.S., García-Moreno, J., Sorenson, M.D., and Mindell, D.P. 2008. Strong mitochondrial DNA support for a Cretaceous origin of modern avian lineages. BMC Biology, 6:6.

Chambers, L.M., Pringle, M., Fitton, G., Larsen, L.M., Pedersen, A.K., and Parrish, R. 2003. Recalibration of the Palaeocene-Eocene boundary (P-E) using high precision $\mathrm{U}-\mathrm{Pb}$ and $\mathrm{Ar}-\mathrm{Ar}$ isotopic dating. In Abstracts of the EGS-AGU-EUG Joint Assembly, Nice, France, 6th-11th April 2003.

Chandler, A.C. 1916. A study of the structure of feathers, with reference to their taxonomic significance. Publications in Zoology of the University of California (Berkeley), 13:243-446.

Chatterjee, S. 2002. The morphology and systematics of Polarornis, a Cretaceous Loon (Aves: Gaviidae) from Antarctica, p. 125-155. In Zhou, Z. and Zhang, F. (eds.), Proceedings of the 5th Symposium of the Society of Avian Paleontology and Evolution, Beijing, 1-4 June 2000. Science Press, Beijing.

Chew, A.E. and Oheim, K.B. 2013. Diversity and climate change in the middle-late Wasatchian (early Eocene) Willwood Formation, central Bighorn Basin, Wyoming. Palaeogeography, Palaeoclimatology, Palaeoecology, 369:67-78.

Clarke, J.T., Warnock, R.C.M., and Donoghue, P.C.J. 2011. Establishing a time-scale for plant evolution. New Phytologist, 192:266-301.

Cohen, K.M., Finney, S., and Gibbard, P.L. 2013. The ICS International Chronostratigraphic Chart. Episodes, 36:199-204.

Cracraft, J. 1985. Monophyly and phylogenetic relationships of the Pelecaniformes: a numerical cladistic analysis. The Auk, 102:834-853.

Donoghue, P.C.J. and Benton, M.J. 2007. Rocks and clocks: calibrating the Tree of Life using fossils and molecules. Trends in Ecology and Evolution, 22:424431.

Drummond, A.J., Ho, S.Y.W., Phillips, M.J., and Rambaut, A. 2006. Relaxed phylogenetics and dating with confidence. PLoS Biology, 4:699. 
Drummond, A.J. and Rambaut, A. 2007. BEAST: Bayesian evolutionary analysis by sampling trees. BMC Evolutionary Biology, 7:214.

Dyke, G.J. and van Tuinen, M. 2004. The evolutionary radiation of modern birds (Neornithes): reconciling molecules, morphology and the fossil record. Zoological Journal of the Linnean Society, 141:153-177.

Egger, H. and Brückl, E. 2006. Gigantic volcanic eruptions and climatic change in the early Eocene. International Journal of Earth Science, 95:1065-1070.

Ericson, P.G.P., Anderson, C.L., Britton, T., Elzanowski, A., Johansson, U.S., Källersjö, M., Ohlson, J.I., Parsons, T.J., Zuccon, D., and Mayr, G. 2006. Diversification of Neoaves: integration of molecular sequence data and fossils. Biology Letters, 2:543-547.

Fain, M.G. and Houde, P. 2004. Parallel radiations in the primary clades of birds. Evolution, 58:2558-2573.

Feduccia, A. 1995. Explosive evolution in Tertiary birds and mammals. Science 267: 637-638.

Felice, R.N. and O'Connor, P.M. 2014. Ecology and caudal skeletal morphology in birds: the convergent evolution of pygostyle shape in underwater foraging taxa. PLoS ONE, 9:e89737.

Friesen, V.L. and Anderson, D.J. Phylogeny and evolution of the Sulidae (Aves: Pelecaniformes): a test of alternative modes of speciation. Molecular Phylogenetics and Evolution, 7:252-260.

Gharbi, A. 1998. Les phosphates marocains. Chroniques de la Recherche Minière, 531-532:127-138.

Gheerbrant, E., Sudre, J., Cappetta, H., Mourer-Chauviré, C., Bourdon, E., larochène, M., Amaghzaz, M., and Bouya, B. 2003. Les localités à mammifères des carrières de Grand Daoui, bassin des Ouled Abdoun, Maroc, Yprésien: premier état des lieux. Bulletin de la Société Géologique de France, 174:279-293.

Gibb, G.C., Kennedy, M., and Penny, D. 2013. Beyond phylogeny: pelecaniform and ciconiiform birds, and long-term niche stability. Molecular Phylogenetics and Evolution, 68:229-238.

Goedert, J.L. 1988. A new Late Eocene species of Plotopteridae (Aves: Pelecaniformes) from Northwestern Oregon. Proceedings of the California Academy of Sciences, 45:97-102.

Gradstein, F.M., Ogg, J.G., Schmitz, M.D., and Ogg, G.M. (eds.) 2012. The Geologic Time Scale 2012, vol. 1. Elsevier Press, Boston, USA.

Grande, L. 2013. The Lost World of Fossil Lake: Snapshots from Deep Time. University of Chicago Press, Chicago, Illinois.

Grande, L. and Buchheim, H.P. 1994. Paleontological and sedimentological variation in early Eocene Fossil Lake. Contributions to Geology, 30:33-56.

Hackett, S.J., Kimball, R.T., Reddy, S., Bowie, R.C.K., Braun, E.L., Braun, M.J., Chojnowski, J.L., Cox, W.A., Han, K.-L., Harshman, J., Huddleston, C.J., Marks, B.D., Miglia, K.J., Moore, W.S., Sheldon, F.H., Steadman, D.W., Witt, C.C., and Yuri, T. 2008. A phylogenomic study of birds reveals their evolutionary history. Science, 320:1763-1768.
Haddrath, O. and Baker, A.J. 2012. Multiple nuclear genes and retroposons support vicariance and dispersal of the palaeognaths, and an Early Cretaceous origin of modern birds. Proceedings of the Royal Society of London B, 279:4617-4625.

Harrison, C.J.O. and Walker, C.A. 1976a. A reappraisal of Prophaethon shrubsolei Andrews (Aves). Bulletin of the British Museum (Natural History) Geology, 27:1-30.

Harrison, C.J.O. and Walker, C.A. 1976b. Birds of the British Upper Eocene. Zoological Journal of the Linnean Society, 59:323-351.

Heath, T.A. 2012. A hierarchical Bayesian model for calibrating estimates of species divergence times. Systematic Biology, 61:793-809.

Ho, S.Y.W. and Phillips, M.J. 2009. Accounting for calibration uncertainty in phylogenetic estimation of evolutionary divergence times. Systematic Biology, 58:367-380.

Hoch, E. 1980. A new Middle Eocene shorebird (Aves: Charadriiformes, Charadrii) with columboid features. Natural History Museum of Los Angeles County Contributions to Science, 330:33-49.

Hou, L.-H. 1982. New form of the Threskiornithidae from the upper Eocene of the Xichuan, Henan. Vertebrata PalAsiatica, 20:196-202. (Chinese, with English summary)

Inoue, J., Donoghue, P.C.J., and Yang, Z. 2010. The impact of the representation of fossil calibrations on Bayesian estimation of species divergence times. Systematic Biology, 59:74-89.

Jetz, W., Thomas, G.H., Joy, J.B., Hartmann, K., and Mooers, A.O. 2012. The global diversity of birds in space and time. Nature, 491:444-448.

Kennedy, M., Holland, B.R., Gray, R.D., and Spencer, H.G. 2005. Untangling long branches: identifying conflicting phylogenetic signals using spectral analysis, Neighbor-Net, and consensus networks. Systematic Biology, 54:620-633.

Kennedy, M. and Page, R.D.M. 2002. Seabird supertrees: combining partial estimates of procellariform phylogeny. The Auk, 119:88-108.

Kristoffersen, A.V. 2002. The avian diversity in the latest Paleocene - earliest Eocene Fur Formation, Denmark. A synopsis. Unpublished PhD Thesis, University of Copenhagen, Copenhagen, Denmark.

Ksepka, D.T., Balanoff, A.M., Bell, M.A., and Houseman, M.D. 2013. Fossil grebes from the Truckee Formation (Miocene) of Nevada and a new phylogenetic analysis of Podicipediformes (Aves). Palaeontology, 56:1149-1169.

Ksepka, D.T., Benton, M.J., Carrano, M.T., Gandolfo, M.A., Head, J.J., Hermsen, E.J., Joyce, W.G., Lamm, K.S., Patané, J.S.L., Phillips, M.J., Polly, P.D., van Tuinen, M., Ware, J.L., Warnock, R.C.M., and Parham, J.F. 2011. Synthesizing and databasing fossil calibrations: divergence dating and beyond. Biology Letters, 7:801-803. 
Ksepka, D.T. and Clarke, J.A. 2010. The basal penguin (Aves: Sphenisciformes) Perudyptes devriesi and a phylogenetic evaluation of the penguin fossil record. Bulletin of the American Museum of Natural History, 337:1-77.

Ksepka, D.T. and Clarke, J.A. 2015. Phylogenetically vetted and stratigraphically constrained fossil calibrations within Aves. Palaeontologia Electronica, 18.1.3FC; 1-25; palaeo-electronica.org/content/fc-3.

Ksepka, D.T. and Thomas, D.B. 2012. Multiple Cenozoic invasions of Africa by penguins (Aves, Sphenisciformes). Proceedings of the Royal Society of London $B, 279: 1027-1032$.

Kuiper, K.F., Deino, A., Hilgen, F.J., Krijgsman, W., Renne, P.R., and Wijbrans, J.R. 2008. Synchronizing rock clocks of Earth history. Science, 320:500-504.

Lee, M.S.Y. and Skinner, A. 2011. Testing fossil calibrations for vertebrate molecular trees. Zoologica Scripta, 40:538-543.

Legendre, S. and Lévêque, F. 1997. Étalonnage de l'échelle biochronologique mammalienne du Paléogène d'Europe occidentale : vers une intégration à l'échelle globale, p. 461-473. In Aguilar, J.-P., Legendre, S., and Michaux, J. (eds.), Actes du Congrès BiochroM'97. Mémoires et Travaux de l'École Pratique des Hautes Études, Institut de Montpellier 2, France.

Lindow, B.E.K. 2007. The early evolution of modern birds: fossil evidence from the Lower Eocene Fur Formation of Denmark. Unpublished PhD Thesis, University College Dublin, Dublin, Ireland.

Lindow, B.E.K. and Dyke, G.J. 2006. Bird evolution in the Eocene: climate change in Europe and a Danish fossil fauna. Biological Reviews, 81:483-499.

Livezey, B.C. and Zusi, R.L. 2006. Higher-order phylogeny of modern birds (Theropoda, Aves: Neornithes) based on comparative anatomy. I. Methods and characters. Bulletin of the Carnegie Museum of Natural History, 37:1-544.

Livezey, B.C. and Zusi, R.L. 2007. Higher-order phylogeny of modern birds (Theropoda, Aves: Neornithes) based on comparative anatomy. II. Analyses and discussion. Zoological Journal of the Linnean Society, 149:1-95.

Longrich, N.R., Tokaryk, T., and Field, D.J. 2011. Mass extinction of birds at the Cretaceous-Paleogene (K$\mathrm{Pg}$ ) boundary. Proceedings of the National Academy of Sciences USA, 108(37):15253-15257.

Louchart, A., Tourment, N., and Carrier, J. 2011. The earliest known pelican reveals 30 million years of evolutionary stasis in beak morphology. Journal of Ornithology, 152:15-20.

Lydekker, R. 1891. Catalogue of the fossil birds in the British Museum (Natural History). British Museum (Natural History), London, UK.

Mayr, G. 2001. A cormorant from the late Oligocene of Enspel, Germany (Aves, Pelecaniformes, Phalacrocoracidae). Senckenbergiana Lethaea, 81:329-333.
Mayr, G. 2002a. A contribution to the osteology of the middle Eocene ibis Rhynchaeites messelensis (Aves: Threskiornithidae: Rhynchaeitinae nov. subfam.). Neues Jahrbuch für Geologie und Paläontologie, Monatshefte, 2002:501-512.

Mayr, G. 2002b. A skull of a new pelecaniform bird from the Middle Eocene of Messel, Germany. Acta Palaeontologica Polonica, 47:507-512.

Mayr, G. 2004. A partial skeleton of a new fossil loon (Aves, Gaviiformes) from the early Oligocene of Germany with preserved stomach content. Journal of Ornithology, 145:281-286.

Mayr, G. 2005. Tertiary plotopterids (Aves, Plotopteridae) and a novel hypothesis on the phylogenetic relationships of penguins (Spheniscidae). Journal of Zoological Systematics and Evolutionary Research, 10:111.

Mayr, G. 2006. A specimen of Eocuculus Chandler, 1999 (Aves, ? Cuculidae) from the early Oligocene of France. Geobios, 39:865-872.

Mayr, G. 2007. A small representative of the Phalacrocoracoidea (cormorants and anhingas) from the Late Oligocene of Germany. The Condor, 109:929-942.

Mayr, G. 2009a. Paleogene Fossil Birds. Springer, Heidelberg, Germany.

Mayr, G. 2009b. A dwarf species of the Phalacrocoracoidea (cormorants and anhingas) from the early Miocene of Germany. Ibis, 151:392-395.

Mayr, G. 2009c. A small loon and a new species of large owl from the Rupelian of Belgium (Aves: Gaviiformes, Strigiformes). Paläontologische Zeitschrift, 83:247-254.

Mayr, G. 2011a. Metaves, Mirandornithes, Strisores and other novelties-a critical review of the higher-level phylogeny of neornithine birds. Journal of Zoological Systematics and Evolutionary Research, 49:58-76.

Mayr, G. 2011b. Cenozoic mystery birds - on the phylogenetic affinities of bony-toothed birds (Pelagornithidae). Zoologica Scripta, 40:448-467.

Mayr, G. 2014. The origins of crown group birds: molecules and fossils. Palaeontology, 57:231-242.

Mayr, G. 2015a. New remains of the Eocene Prophaethon and the early evolution of tropicbirds (Phaethontiformes), Ibis, 157(1):54-67.

Mayr, G. 2015b. A new skeleton of the late Oligocene "Enspel cormorant" - from Oligocorax to Borvocarbo, and back again. Palaeobiodiversity and Palaeoenvironments, 95:87-101.

Mayr, G. and Bertelli, S. 2011. A record of Rhynchaeites (Aves, Threskiornithidae) from the early Eocene Fur Formation of Denmark, and the affinities of the alleged parrot Mopsitta. Palaeobiodiversity and Palaeoenvironments, 91:229-236.

Mayr, G. and Poschmann, M. 2009. A loon leg (Aves, Gaviidae) with crocodilian tooth from the late Oligocene of Germany. Waterbirds, 32:468-471. 
Mayr, G. and Smith, R. 2002a. A new record of the Prophaethontidae (Aves: Pelecaniformes) from the Middle Eocene of Belgium. Bulletin de I'Institut Royal des Sciences Naturelles de Belgique, 72:135-138.

Mayr G, and Smith R. 2002b Avian remains from the lowermost Oligocene of Hoogbutsel (Belgium). Bulletin de I'Institut Royal des Sciences Naturelles de Belgique Sciences de la Terre 2002, 72:139-150.

Mayr, G. and Zvonok, E. 2011. Middle Eocene Pelagornithidae and Gaviiformes (Aves) from the Ukrainian Paratethys. Palaeontology, 54:1347-1359.

Mayr, G., Zvonok, E., and Gorobets, L. 2013. The tarsometatarsus of the middle Eocene loon Colymbiculus udovichenkoi, p. 17-22. In Göhlich, U.B. and Kroh, A. (eds.), Paleornithological research 2013 Proceedings of the 8th International Meeting of the Society of Avian Paleontology and Evolution. Natural History Museum Vienna, Vienna.

McCormack, J.E., Harvey, M.G., Faircloth, B.C., Crawford, N.G., Glenn, T.C., and Brumfield, R.T. 2013. A phylogeny of birds based on over 1,500 loci collected by target enrichment and high-throughput sequencing. PLOS ONE, 8(1):e54848.

Mertz, D.F., Renne, P.R., Wuttke, M., and Mödden, C. 2007. A numerically calibrated reference level (MP28) for the terrestrial mammal-based biozonation of the European Upper Oligocene. International Journal of Earth Sciences, 96:353-361.

Mlíkovský, J. 2002. Cenozoic birds of the World. Part 1: Europe. Ninox Press, Prague.

Mlíkovský, J. 2007. Taxonomic identity of Eostega lebedinskyi Lambrecht, 1929 (Aves) from the Middle Eocene of Romania. Annalen des Naturhistorischen Museums in Wien, Serie A 109:19-27.

Mourer-Chauviré, C. 1982. Les oiseaux fossils des Phosphorites du Quercy (Eocéne supérieur a Oligocéne supérieur): implications paleobiogéographiques, p. 413-426. In Buffetaut E., Janvier, P., Rage, J.-C., and Tassy, P. (eds.), Phylogénie et paléobiogéographie, Livre jubilaire en l'honneur de Robert Hoffstetter. Geobios, Mémoire Spécial 6, Lyon, France.

Mourer-Chauviré, C., 1985. Les Todidae (Aves, Coraciiformes) des Phosphorites du Quercy (France). Proceedings of the Koninklijke Nederlandse Akademie van Wetenschappen Series B, 88:407-414.

Müller, J. and Reisz, R.R. 2005. Four well-constrained calibration points from the vertebrate fossil record for molecular clock estimates. BioEssays, 27:10691075.

Nesbitt, S.J. and Stocker, M.R. 2008. The vertebrate assemblage of the Late Triassic Canjilon Quarry (northern New Mexico, USA), and the importance of apomorphy-based assemblage comparisons. Journal of Vertebrate Paleontology, 28:1063-1072.

Nunn, G.B. and Stanley, S.E. 1998. Body size effects and rates of cytochrome $b$ evolution in tube-nosed seabirds. Molecular Biology and Evolution, 15:13601371.
Office Chérifien des Phosphates. 1989. The phosphate basins of Morocco, p. 301-3211. In Notholt, A.J.G., Sheldon, R.P., and Davidson, D.F. (eds.), Phosphate Deposits of the World, Vol. 2: Phosphate Rock Resources. Cambridge University Press, Cambridge, U.K.

Olson, S.L. 1977. A Lower Eocene frigatebird from the Green River formation of Wyoming (Pelecaniformes: Fregatidae). Smithsonian Contributions to Paleobiology, 35:1-33.

Olson, S.L. 1984. A hamerkop from the Early Pliocene of South Africa (Aves: Scopidae). Proceedings of the Biological Society of Washington, 97(4):736-740.

Olson, S.L. 1985. The fossil record of birds, p. 79-238. In: Farner D.S., King J.R., and Parkes K.C. (eds), Avian Biology Vol. 8. Academic Press, New York.

Olson, S.L. 1992. Neogaeornis wetzeli Lambrecht, a Cretaceous loon from Chile (Aves: Gaviidae). Journal of Vertebrate Paleontology, 12:122-124.

Olson, S.L. 1994. A giant Presbyornis (Aves: Anseriformes) and other birds from the Paleocene Aquia Formation of Maryland and Virginia. Proceedings of the Biological Society of Washington, 107:429-435.

Olson, S.L. and Matsuoka, H. 2005. New specimens of the early Eocene frigatebird Limnofregata (Pelecaniformes: Fregatidae), with the description of a new species. Zootaxa, 1046:1-15.

Olson, S.L. and Parris, D.C. 1987. The Cretaceous birds of New Jersey. Smithsonian Contributions to Paleobiology, 63:1-22.

Olson, S.L. and Walker, C.A. 1997. A trans-Atlantic record of the fossil tropicbird Heliadornis ashbyi (Aves: Phaethontidae) from the Miocene of Belgium. Proceedings of the Biological Society of Washington, 110:624-628.

Pacheco, M.A., Battistuzzi, F.U., Lentino, M., Aguilar, R.F., Kumar, S., and Escalante, A.A. 2011. Evolution of modern birds revealed by mitogenomics: timing the radiation and origin of major orders. Molecular Biology and Evolution, 28:1927-1942.

Parham, J.F., Donoghue, P.C.J., Bell, C.J., Calway, T.D., Head, J.J., Holroyd, P.A., Inoue, J.G., Irmis, R.B., Joyce, W.G., Ksepka, D.T., Patané, J.S.L., Smith, N.D., Tarver, J.E., van Tuinen, M., Yang, Z., Angielczyk, K.D., Greenwood, J., Hipsley, C.A., Jacobs, L., Makovicky, P.J., Müller, J., Smith, K.T., Theodor, J.M., Warnock, R.C.M., and Benton, M.J. 2012. Best practices for justifying fossil calibrations. Systematic Biology, 61:346-359.

Peters, D.S. 1983. Die "Schnepfenralle" Rhynchaeites messelensis Wittich 1898 ist ein Ibis. Journal für Ornithologie, 124:1-27.

Rasmussen, D.T., Olson, S.L., and Simons, E.L. 1987. Fossil birds from the Oligocene Jebel Qatrani Formation, Fayum Province, Egypt. Smithsonian Contributions to Paleobiology, 62:1-20. 
Ronquist, F., Klopfstein, S., Vilhelmsen, L., Schulmeister, S., Murray, D., and Rasnitsyn, A.P. 2012. A total-evidence approach to dating fossils, applied to the early radiation of the Hymenoptera. Systematic Biology, 61:973-999.

Roux, T. 2002. Deux fossiles d'oiseaux de l'Oligocéne inférieur du Luberon. Courrier Scientifique du Parc Naturel Régional du Luberon, 6:38-57.

Slack, K.E., Jones, C.M., Ando, T., Harrison, G.L., Fordyce, R.E., Arnason, U., and Penny, D. 2006. Early penguin fossils, plus mitochondrial genomes, calibrate avian evolution. Molecular Biology and Evolution, 23:1144-1155.

Simons, E.L.R., Hieronymus, T.L., and O'Connor, P.M. 2011. Cross sectional geometry of the forelimb skeleton and flight mode in pelecaniform birds. Journal of Morphology, 272:958-971.

Smith, K.T. and Gauthier, J.A. 2013. Early Eocene lizards of the Wasatch Formation near Bitter Creek, Wyoming: diversity and paleoenvironment during an interval of global warming. Bulletin of the Peabody Museum of Natural History, 54:135-230.

Smith, M.E., Chamberlain, K.R., Singer, B.S., and Carroll, A.R. 2010. Eocene clocks agree: Coeval ${ }^{40} \mathrm{Ar} /$ ${ }^{39} \mathrm{Ar}, \mathrm{U}-\mathrm{Pb}$, and astronomical ages from the Green River Formation. Geology, 38:527-530.

Smith, N.A. 2013. Avian fossils from the Early Miocene Moghra Formation of Egypt. Ostrich. African Journal of Ornithology, 84:181-189.

Smith, N.D. 2010. Phylogenetic analysis of Pelecaniformes (Aves) based on osteological data: implications for waterbird phylogeny and fossil calibration studies. PLOS ONE, 5:e13354.

Smith, N.D. 2012. Body mass and foraging ecology predict evolutionary patterns of skeletal pneumaticity in the diverse "Waterbird" clade. Evolution, 66:10591078.

Smith, N.D., Grande, L., and Clarke, J.A. 2013. A new species of Threskiornithidae-like bird (Aves, Ciconiiformes) from the Green River Formation (Eocene) of Wyoming. Journal of Vertebrate Paleontology, 33:363-381.

Stidham, T.A. 2015. A new species of Limnofregata (Pelecaniformes: Fregatidae) from the Early Eocene Wasatch Formation of Wyoming: implications for palaeoecology and palaeobiology. Palaeontology, 58(2):239-249.

Stidham, T.A., Holroyd, P.A., Gunnell, G.F., Ciochon, R.L., Tsubamoto, T., Egi, N., and Takai, M. 2005. An ibis-like bird (Aves: cf. Threskiornithidae) from the late middle Eocene of Myanmar. Contributions from the University of Michigan Museum of Paleontology, 31:179-184.

Stidham, T.A., Krishan, K., Singh, B., Ghosh, A., and Patnaik, R. 2014. A pelican tarsometatarsus (Aves: Pelecanidae) from the latest Pliocene Siwaliks of India. PLoS ONE, 9:e111210.
Storer, R.W. 1956. The fossil Loon, Colymboides minutus. Condor, 58:413-426.

Storey, M., Duncan, R.A., and Swisher III, C.C. 2007. Paleocene-Eocene thermal maximum and the opening of the Northeast Atlantic. Science, 316:587-589.

Thorne, J.L., Kishino, H., and Painter, I.S. 1998. Estimating the rate of evolution of the rate of molecular evoIution. Molecular Biology and Evolution, 15:16471657.

Torres, C.R., Ogawa, L.M., Gillingham, M.A.F., Ferrari, B., and van Tuinen, M. 2014. A multi-locus inference of the evolutionary diversification of extant flamingos (Phoenicopteridae). BMC Evolutionary Biology, 14:36.

van Tets, G.F., Rich, P.V., and Marino-Haiwardoyo, H.R. 1989. A reappraisal of Protoplotus beauforti from the early Tertiary of Sumatra and the basis of a new pelecaniform family. Bulletin of the Geological Research and Development Centre, Paleontology Series, 5:57-75.

van Tuinen, M., Butvill, D.B., Kirsch, J.A.W., and Hedges, S.B. 2001. Convergence and divergence in the evolution of aquatic birds. Proceedings of the Royal Society of London, B, 268:1-6.

van Tuinen, M., Ramakrishnan, U., and Hadly, E.A. 2004. Investigating the effect of environmental change on biotic evolution: genetic contributions, current work and future developments. Philosophical Transactions of the Royal Society of London, Series A, 362:2795-2820.

van Tuinen, M., Stidham, T.A., and Hadley, E.A. 2006. Tempo and mode of modern bird evolution observed with large-scale taxonomic sampling. Historical Biology, 18:205-221.

Walker, J.D., Geissman, J.W., Bowring, S.A., and Babcock, L.E. 2013. The Geological Society of America geologic time scale. GSA Bulletin, 125:259-272.

Wang, M., Mayr, G., Zhang, J., and Zhou, Z. 2012. New bird remains from the middle Eocene of Guangdong, China. Acta Palaeontologica Polonica, 57:519-526.

Warnock, R.C.M., Yang, Z., and Donoghue, P.C.J. 2012. Exploring uncertainty in the calibration of the molecular clock. Biology Letters, 8:156-159.

Westerhold, T., Röhl, U., McCarren, H.K., and Zachos, J.C. 2009. Latest on the absolute age of the Paleocene-Eocene Thermal Maximum (PETM): new insights from exact stratigraphic position of key ash layers +19 and -17 . Earth and Planetary Science Letters, 287:412-419.

Whateley, M.K.G. and Jordon, G.R. 1989. Fan-deltalacustrine sedimentation and coal development in the Tertiary Ombilin Basin, W Sumatra. Indonesia Geological Society Special Publication, 41:317-332.

Wittich, E. 1898. Beitráge zur Kenntnis der Messeler Braunkohle und ihrer Fauna. Abhandlungen der Gross herzoglieb Hessischen geologischen Landensanstalt zu Darmstadt, 3:79-147. 
Woodburne, M.O., MacFadden, B.J., Case, J.A., Springer, M.S., Pledge, N.S., Power, J.D., Woodburne, J.M., and Springer, K.B. 1994. Land mammal biostratigraphy and magnetostratigraphy of the Etadunna Formation (Late Oligocene) of South Australia. Journal of Vertebrate Paleontology, 13:483-515.

Worthy, T. H. 2012. A new species of Oligo-Miocene darter (Aves: Anhingidae) from Australia. The Auk, 129:96-104.
Yang, Z. 2007. PAML 4: Phylogenetic Analysis by Maximum Likelihood. Molecular Biology and Evolution, 24:1586-1591.

Yang, F.L. and Rananala, B. 2006. Bayesian estimation of species divergence times under a molecular clock using multiple fossil calibrations with soft bounds. Molecular Biology and Evolution, 23:212-226. 